\title{
Selected Meteorological Data for an Arid Site Near Beatty, Nye County, Nevada, Calendar Year 1988
}

By James L. Wood, Kevin J. Hill, and B.J. Andraski

U.S. GEOLOGICAL SURVEY

Open-File Report 92-61

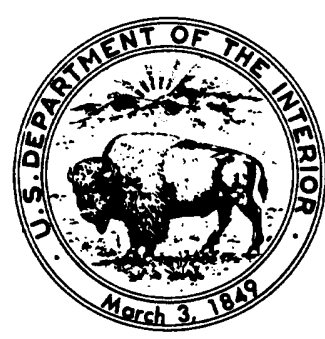

Carson City, Nevada 1992 


\title{
U.S. DEPARTMENT OF THE INTERIOR
}

\author{
MANUEL LUJAN, JR., Secretary
}

\section{U.S. GEOLOGICAL SURVEY}

Dallas L. Peck, Director

\begin{abstract}
Any use of trade, product, or firm names in this publication is for descriptive purposes only and does not constitute endorsement by the U.S. Government
\end{abstract}

For additional information (after April 4, 1992), write to:

U.S. Geological Survey

333 West Nye Lane

Carson City, NV 89706
Copies of this report may be purchased from:

U.S. Geological Survey Books and Open-File Reports Section Box 25425, Federal Center Denver, CO 80225 


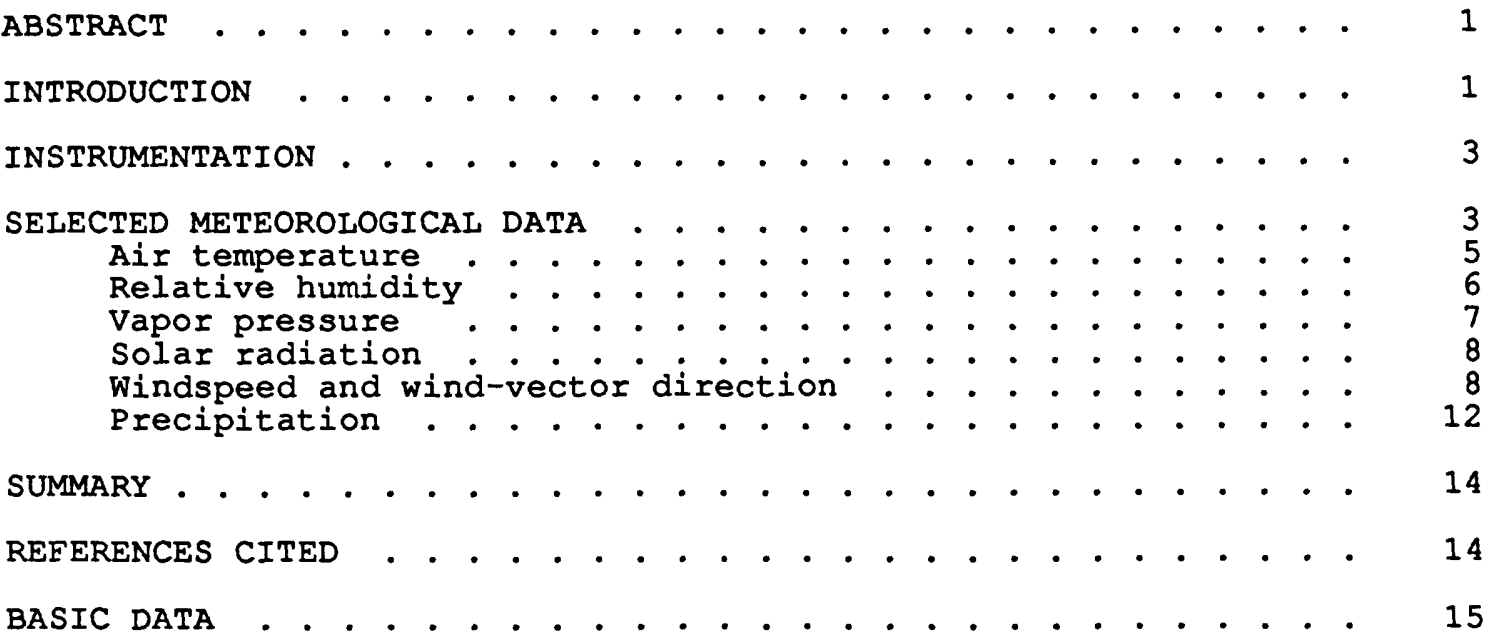

\section{IILUSTRATIONS}

Figure 1. Map showing location of study site and adjacent waste-disposal facility

2. Map showing location of weather station and related unsaturated-zone monitoring shaft, psychrometer borehole, and neutron-probe access tubes at the study site . . . . . . . . .

3-7. Graphs showing meteorological data for 1988, computed from hourly averaged values:

3. Daily maximum, mean, and minimum air temperature

4. Daily mean relative humidity . . . . . . . . .

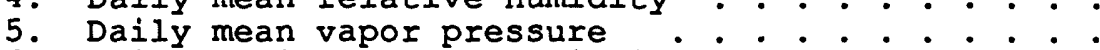

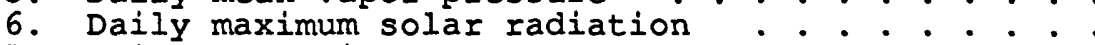

7. Daily mean windspeed . . . . . . . . . . . . .

8. Diagrams showing percentage of time wind is from given direction for each month during 1988

9. Graphs showing precipitation at or near study site for $1988^{\circ}$

\section{TABLES}

Table 1. Monthly maximum, minimum, and mean air temperatures at study site for 1988

2. Daily total precipitation at study site for 1988 . . 12

3. Summary of meteorological data collected at study site in 1988 ................. 
CONVERSION FACTORS AND VERTICAL DATUM

$\begin{array}{lcl}\text { Multiply } & \text { By } & \text { To obtain } \\ \text { kilometer }(\mathrm{km}) & 0.6214 & \text { mile } \\ \text { kilopascal (kPa) } & 0.1450 & \text { pounds per square inch } \\ \text { meter }(\mathrm{m}) & 3.281 & \text { feet } \\ \text { meter per second (m/s) } & 3.281 & \text { feet per second } \\ \text { millimeter (mm) } & 0.03937 & \text { inch } \\ \text { millimeter per hour (mm/hr) } & 25.40 & \text { inch per hour } \\ \text { watt per square } & 0.005290 & \text { British Thermal Unit per } \\ \text { meter (W/mare foot per minute }\end{array}$

SEA LEVEI

In this report, "sea level" refers to the National Geodetic Vertical Datum of 1929 (NGVD of 1929, formerly called "Sea-Level Datum of 1929"), which is derived from a general adjustment of the first-order leveling networks of both the United States and Canada. 


\title{
Selected Meteorological Data for an Arid Site Near Beatty, Nye County, Nevada, Calendar Year 1988
}

\author{
By James L. Wood, Kevin J. Hill, and B.J. Andraski
}

\begin{abstract}
Selected meteorological data were collected at a study site adjacent to a low-level radioactive-waste burial facility near Beatty, Nevada, for calendar year 1988. Data were collected in support of ongoing studies to estimate the potential for downward movement of radionuclides into the unsaturated sediments beneath waste-burial trenches at the facility. The data include air temperature, relative humidity, vapor pressure, incident solar radiation, windspeed, wind direction, and precipitation. The data are summarized in tables and graphs.

Instrumentation used at the site is discussed. The discussion includes the type, reported accuracy, and mounting height of each sensor.

In 1988, the average hourly air temperatures ranged from -10.2 degrees Celsius, in December, to 45.3 degrees Celsius, in July. Hourly averaged relative humidity ranged from about 12 percent to over 80 percent. Hourly vapor pressures ranged from 0.09 to $2.22 \mathrm{kilopascals.} \mathrm{Daily} \mathrm{values} \mathrm{for}$ maximum incident solar radiation ranged from 63 to 1,064 watts per square meter. Daily mean windspeed ranged from 1.2 to 7.8 meters per second. Monthly wind-direction patterns are shown in a series of diagrams in which wind direction is summed over 10-degree arcs from hourly averaged data. Total precipitation for 1988 was 104.5 millimeters, with over 70 percent occurring from January through May.
\end{abstract}

\section{INTRODUCTION}

Meteorological data were collected near the low-level radioactivewaste burial facility near Beatty, Nev., in support of ongoing studies (Andraski, 1990; Fischer, 1990) to estimate the potential for downward movement of radionuclides into the unsaturated sediments beneath wasteburial trenches at the facility (figure 1B). This report presents and summarizes meteorological data collected for calendar year 1988 . It is one in a series of meteorological data reports for this site (Wood and Fischer, 1991, 1992). The meteorological data collected include air temperature, relative humidity, vapor pressure, incident solar radiation, windspeed, wind direction, and precipitation.

The waste-burial facility on the Amargosa Desert, $17 \mathrm{~km}$ southeast of Beatty and $169 \mathrm{~km}$ northwest of Las Vegas, Nev. (figure 1A), has been operating since 1962. The disposal facility was the first commercially operated in the United States. At this facility, wastes are emplaced in 2- to 15-m deep trenches and covered by back filling with previously excavated materials. The Amargosa Desert in the vicinity of the waste-burial facility is a northwest trending valley about $13 \mathrm{~km}$ wide. Vegetation is sparse, with creosote bush (Larrea tridentata) being the dominant species.

The study site (altitude, $847 \mathrm{~m}$ above sea level) is in one of the most arid parts of the United States. Precipitation is highly variable. Mean annual precipitation is about $114 \mathrm{~mm}$ at Beatty (altitude, 1,005 m), and $74 \mathrm{~mm}$ at Amargosa Valley (formerly Lathrop Wells; altitude, $817 \mathrm{~m}$ ), $30 \mathrm{~km}$ southeast of the site (Nichols, 1987, p. 15). No perennial streams are within $16 \mathrm{~km}$ of the site and the dry bed of Amargosa River is the principal drainage channel (figure 1A). 

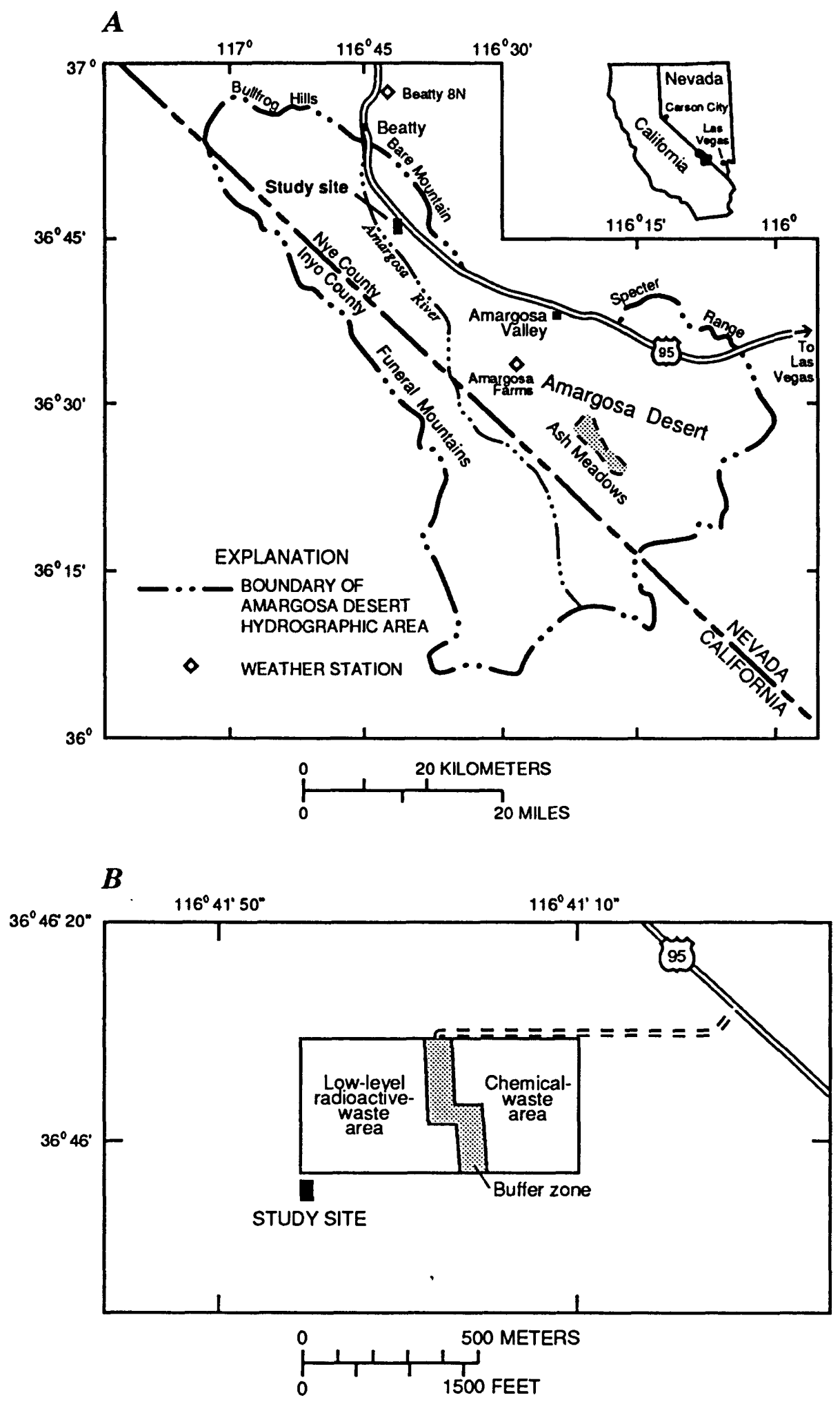

FIGURE 1.--Location of study site and adjacent waste-disposal facility. 
A detailed view of part of the study site is shown in figure 2 . The site is enclosed by a chain-link fence $2 \mathrm{~m}$ high topped with $1 / 2 \mathrm{~m}$ of razor ribbon and is patrolled by security from the adjacent commercial waste-disposal facility; this provides protection against vandalism. Site-maintenance visits are made on a monthly basis and after significant precipitation events. In addition to the meteorological station data, unsaturated-zone data are collected from three neutron-probe access tubes and from sensors installed at several depths in a monitoring shaft (figure 2). An undisturbed area is maintained on one side of the shaft site where no foot or vehicle traffic is allowed except on a designated foot path. A description of this unsaturated-zone monitoring is presented by Morgan and Fischer (1984).

\section{INSTRUMENTATION}

Meteorological sensors consisting of an air temperature and relative humidity sensor, silicon pyranometer, anemometer, wind vane, and tipping-bucket rain gage were installed in the fall of 1984. All sensors were factory calibrated prior to installation. Data from the sensors were recorded using a Campbell Scientific, Inc. (CSI) CR21 datalogger. All instruments are mounted on a CSI CMIO tripod. Both the anemometer and wind vane are mounted $3.4 \mathrm{~m}$ above land surface. The air temperature/relative humidity (RH) probe is mounted inside a CSI model 041 sensor shield $1.7 \mathrm{~m}$ above land surface. The tipping-bucket rain gage is mounted $2.2 \mathrm{~m}$ above land surface and the silicon pyranometer $3.7 \mathrm{~m}$ above land surface. All heights are approximate. The CSI tripod is located approximately $40 \mathrm{~m}$ from the CSI datalogger, which is housed in a shed on the site (figure 2 ).

The anemometer is a model 014A supplied by MET ONE ${ }^{1}$ with an accuracy of 1.5 percent and a threshold of $0.45 \mathrm{~m} / \mathrm{s}$. The wind vane is a model $024 \mathrm{~A}$ also from MET ONE and has a specified accuracy of \pm 5 degrees and a threshold of $0.45 \mathrm{~m} / \mathrm{s}$. The temperature/RH probe is a CSI model 207 with a temperature accuracy of $\pm 0.4^{\circ} \mathrm{C}$ in a range of $-33^{\circ} \mathrm{C}$ to $48^{\circ} \mathrm{C}$ and a $\mathrm{RH}$ accuracy of \pm 5 percent over a 12- to 100-percent $\mathrm{RH}$ range. The tipping-bucket rain gage is a Weathermeasure model $\mathrm{P}-501$ with a sensitivity and resolution of $0.25 \mathrm{~mm}$ and an accuracy of 0.5 percent at $12.7 \mathrm{~mm} / \mathrm{hr}$. The silicon pyranometer is a IICOR II200S calibrated against an Eppley Precision Spectral Pyranometer.

\section{SEIECTED METEOROIOGICAI DATA}

Measurements from all meteorological instruments, except the tippingbucket rain gage, were made every 60 seconds. These measurements were used by the CR21 datalogger to compute hourly averages for air temperature, relative humidity, solar radiation, windspeed, wind direction, and a standard deviation of the wind direction. Precipitation was recorded at 5-minute intervals only during events, and totaled for each day. The hourly averaged and totalized precipitation values were automatically retrieved from the datalogger by a Prime minicomputer using telecommunications and a computer program called ADAREPS, which is an acronym for Automatic DAta REtrieval and Processing System (John Walker, U.S. Geological Survey, written commun., 1986). Data from the datalogger were retrieved twice daily. A cassette tape attached to the datalogger was used as a backup to the automatic dataretrieval system. The hourly averaged values were used to compute daily means, maximums, and minimums for air temperature, relative humidity, solar radiation, windspeed, and wind direction, and are summarized in table 3 at the end of this report. Due to communications failures, 13 days during 1988 had missing hourly values, and of these, 5 days in January and 1 day in February had fewer than 20 hourly values reported.

1 All sensor specifications supplied by manufacturers. 


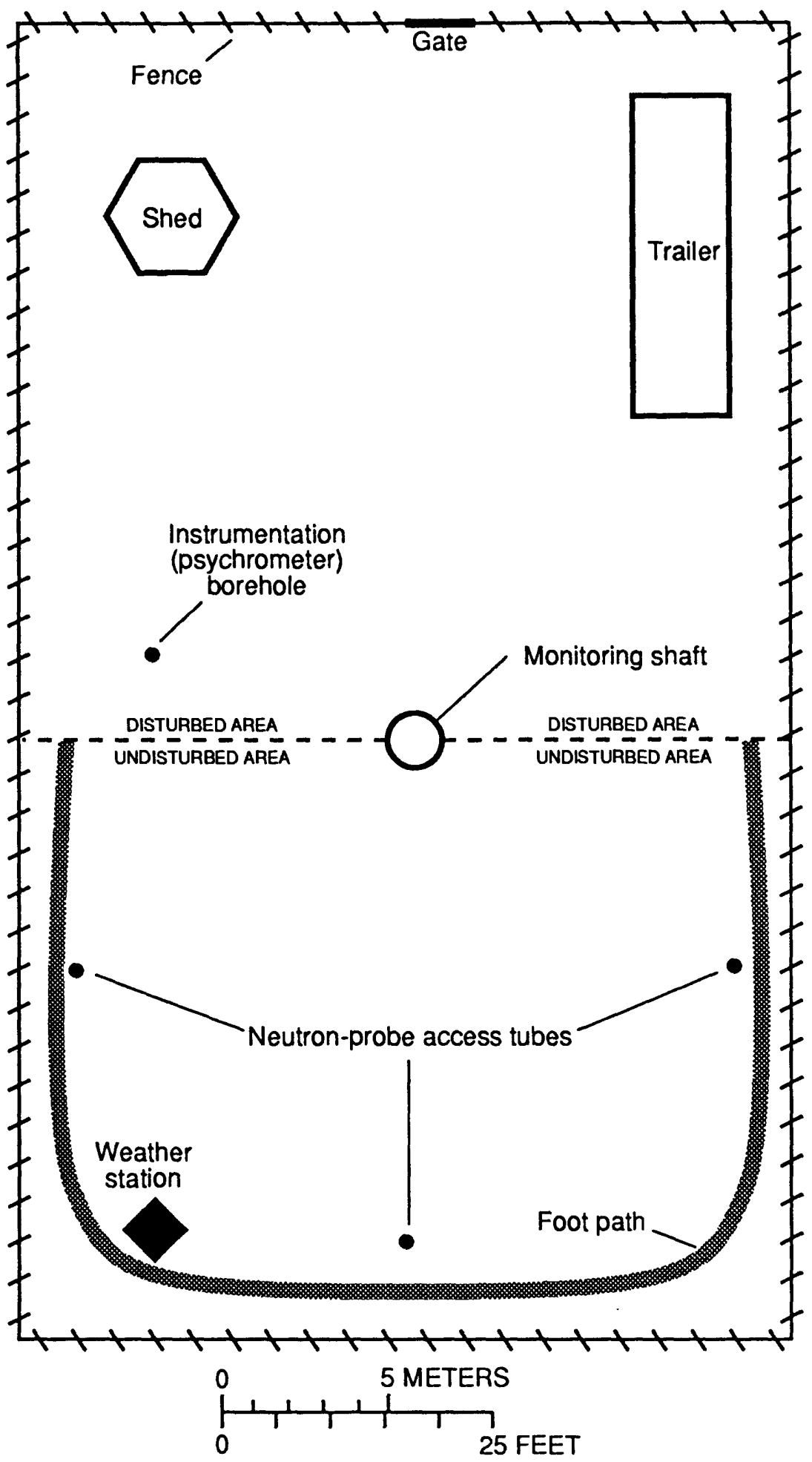

FIGURE 2.--Location of weather station and related unsaturated-zone monitoring shaft, psychrometer borehole, and neutron-probe access tubes at study site. The monitoring shaft is used to measure water potentials and the neutron-probe access tubes are used to measure moisture content. Location of study site is shown in figure 1. 


\section{Air Temperature}

Hourly averaged values of maximum and minimum air temperatures for each month together with a monthly mean value are listed in table 1. The minimum temperature was $-10.2^{\circ} \mathrm{C}$ in December and the maximum was $45.3^{\circ} \mathrm{C}$ in July.

Both seasonal and daily temperature fluctuations are large in the vicinity of the study area. Differences between hourly averaged maximum and minimum temperatures commonly exceeded $25^{\circ} \mathrm{C}$. Daily mean, maximum, and minimum temperatures for 1988 are shown in figure 3.

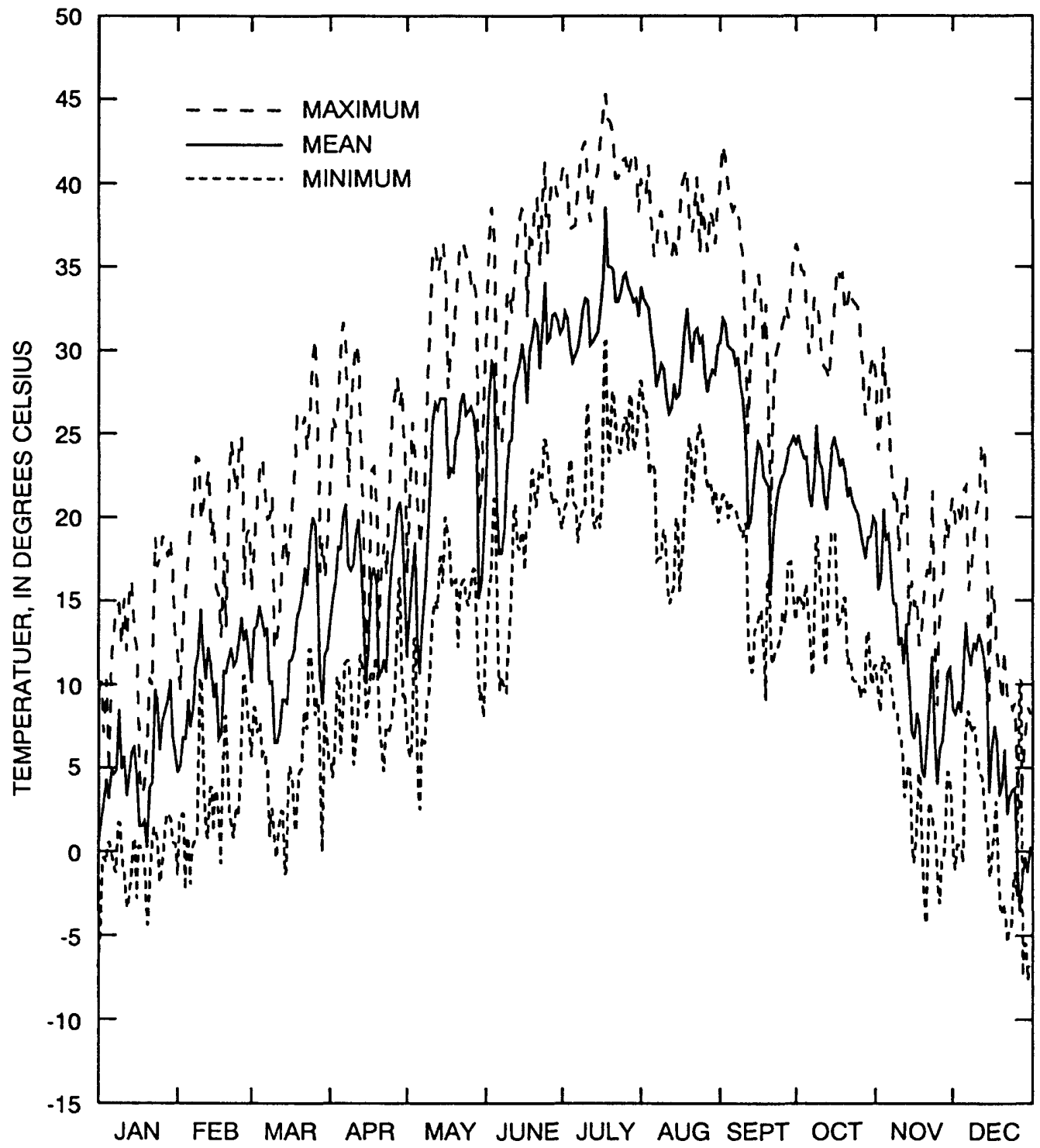

FIGURE 3.--Daily maximum, mean, and minimum air temperatures computed from hourly averaged values for 1988 . 


\begin{tabular}{|c|c|c|c|c|c|}
\hline Month & Maximum ${ }^{1}$ & Day & Minimum ${ }^{1}$ & Day & Mean \\
\hline $\begin{array}{l}\text { January } \\
\text { February } \\
\text { March } \\
\text { April } \\
\text { May } \\
\text { June }\end{array}$ & $\begin{array}{l}18.9 \\
24.8 \\
30.7 \\
31.7 \\
36.5 \\
41.3\end{array}$ & $\begin{array}{r}26 \\
26 \\
26 \\
6 \\
22 \\
24\end{array}$ & $\begin{array}{r}-6.9 \\
-3.9 \\
-2.1 \\
3.8 \\
1.4 \\
8.8\end{array}$ & $\begin{array}{r}1 \\
4 \\
29 \\
2 \\
6 \\
6\end{array}$ & $\begin{array}{r}5.0 \\
10.2 \\
12.2 \\
16.2 \\
21.5 \\
27.8\end{array}$ \\
\hline $\begin{array}{l}\text { July } \\
\text { August } \\
\text { September } \\
\text { October } \\
\text { November } \\
\text { December }\end{array}$ & $\begin{array}{l}45.3 \\
40.9 \\
42.3 \\
36.4 \\
30.2 \\
24.4\end{array}$ & $\begin{array}{r}18 \\
19 \\
2 \\
1 \\
4 \\
12\end{array}$ & $\begin{array}{r}17.8 \\
14.5 \\
7.1 \\
8.8 \\
-4.6 \\
-10.2\end{array}$ & $\begin{array}{r}7 \\
16 \\
19 \\
26 \\
20 \\
27\end{array}$ & $\begin{array}{r}31.6 \\
29.6 \\
24.7 \\
21.9 \\
11.2 \\
6.3\end{array}$ \\
\hline
\end{tabular}

1 Hourly averaged values.

\section{Relative Humidity}

Relative humidity is the ratio of the amount of water vapor in the air at a specific temperature to the maximum amount of water vapor the air can hold at that temperature and is expressed as a percent. Daily mean, maximum, and minimum relative-humidity values computed from hourly averaged values are listed in table 3 . Daily mean relative-humidity values are shown in figure 4. Daily mean values range from about 12 percent (the lower limit of the sensor range) during the drier summer months to more than 80 percent during January storm events.

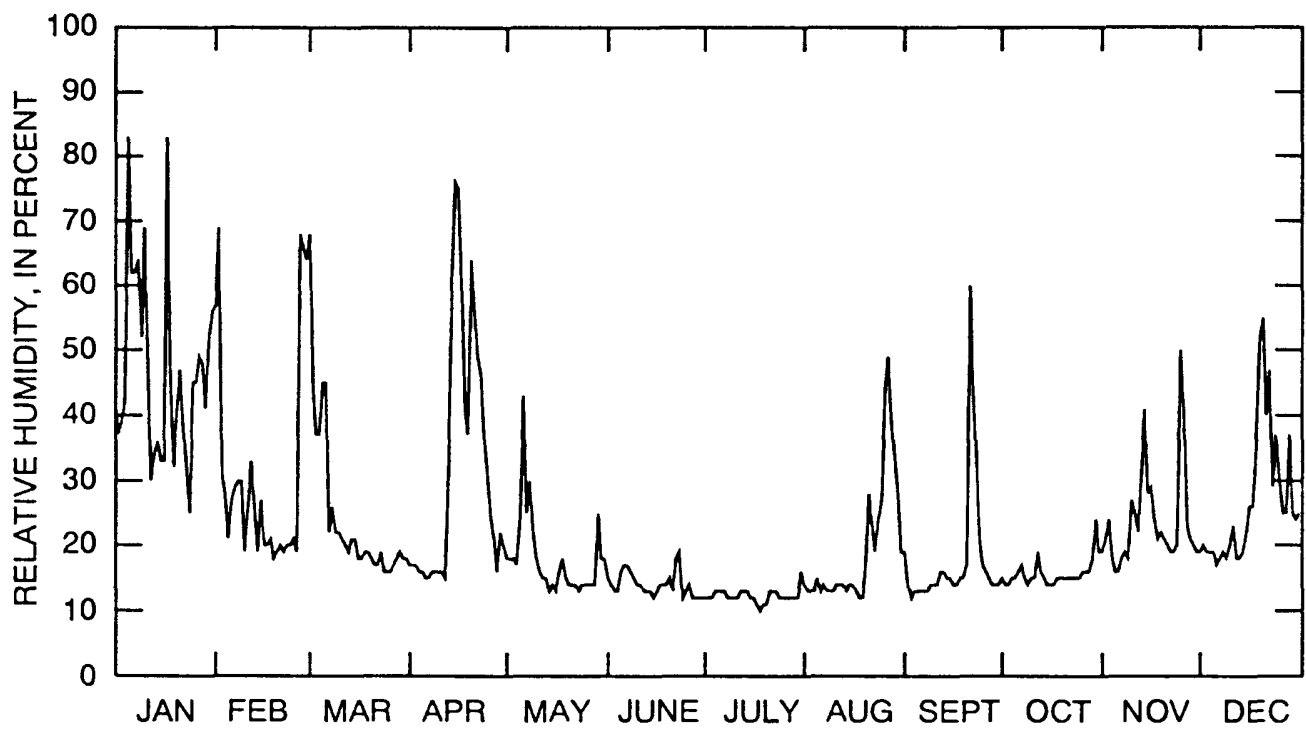

FIGURE 4.--Daily mean relative humidity computed from hourly averaged values for 1988 . 


\section{Vapor Pressure}

Water vapor content of air can be expressed in terms of the partial pressure exerted by the water vapor, or vapor pressure (Campbell, 1986 , p. 21). Hourly vapor pressure at a given ambient air temperature was determined by first calculating the saturation vapor pressure at that particular temperature, which is defined as the highest concentration of water vapor that can exist in equilibrium with a plane, free water surface at a given temperature. This value was obtained by using the formula (Lowe, 1977, p. 100):

$$
E_{s}=a_{0}+a_{1} T+a_{2} T^{2}+a_{3} T^{3}+a_{4} T^{4}+a_{5} T^{5}+a_{6} T^{6}
$$

where

$E_{s}=$ saturation vapor pressure, in millibars:

$\stackrel{S}{T}=$ temperature, in degrees Celsius; and

$a_{i}(i=0,1, \ldots 6)=$ numerical constants for each term of the polynomial.

The result was then divided by 10 to convert from millibars to kilopascals. Ambient vapor pressure was determined by multiplying the hourly saturation vapor pressure by the hourly averaged relative humidity.

Daily mean, maximum, and minimum values of vapor pressure are listed in table 3. Daily mean vapor pressures computed from hourly averaged values of temperature and relative humidity are shown in figure 5 . Hourly vapor pressures ranged from a maximum of $2.22 \mathrm{kPa}$ in August to a minimum of $0.09 \mathrm{kPa}$ in December. Vapor pressures generally have higher base pressures during the warmer summer months and lower base pressures coinciding with cooler winter conditions (figure 5). Vapor-pressure peaks throughout the year generally correlate with precipitation listed in table 2 and shown in figure $9 \mathrm{C}$.

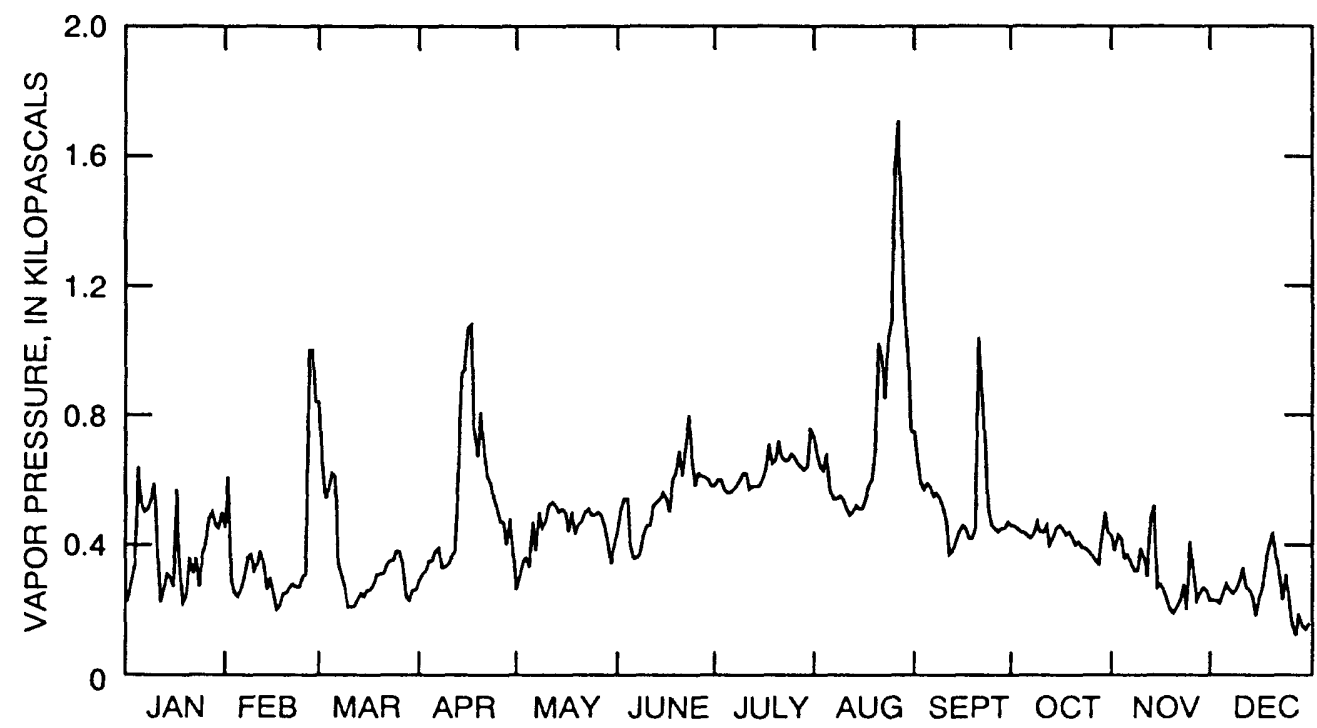

FIGURE 5.--Daily mean vapor pressure computed from hourly averaged values for 1988. 


\section{Solar Radiation}

Daily averaged and maximum incident solar radiation computed from hourly averaged values are listed in table 3 . Incident solar radiation (short wave) is the amount of radiation that reaches the earth without interception. Generally, daily mean and maximum radiation were highest from May through September and lowest from November through February, coinciding with seasonal cycles.

Maximum solar-radiation values computed from hourly averaged values for each day are shown in figure 6 . The daily maximum solar-radiation values, for days with 24 values, ranged from $63 \mathrm{~W} / \mathrm{m}^{2}$ on January 5 to $1,064 \mathrm{~W} / \mathrm{m}^{2}$ on July 13 .

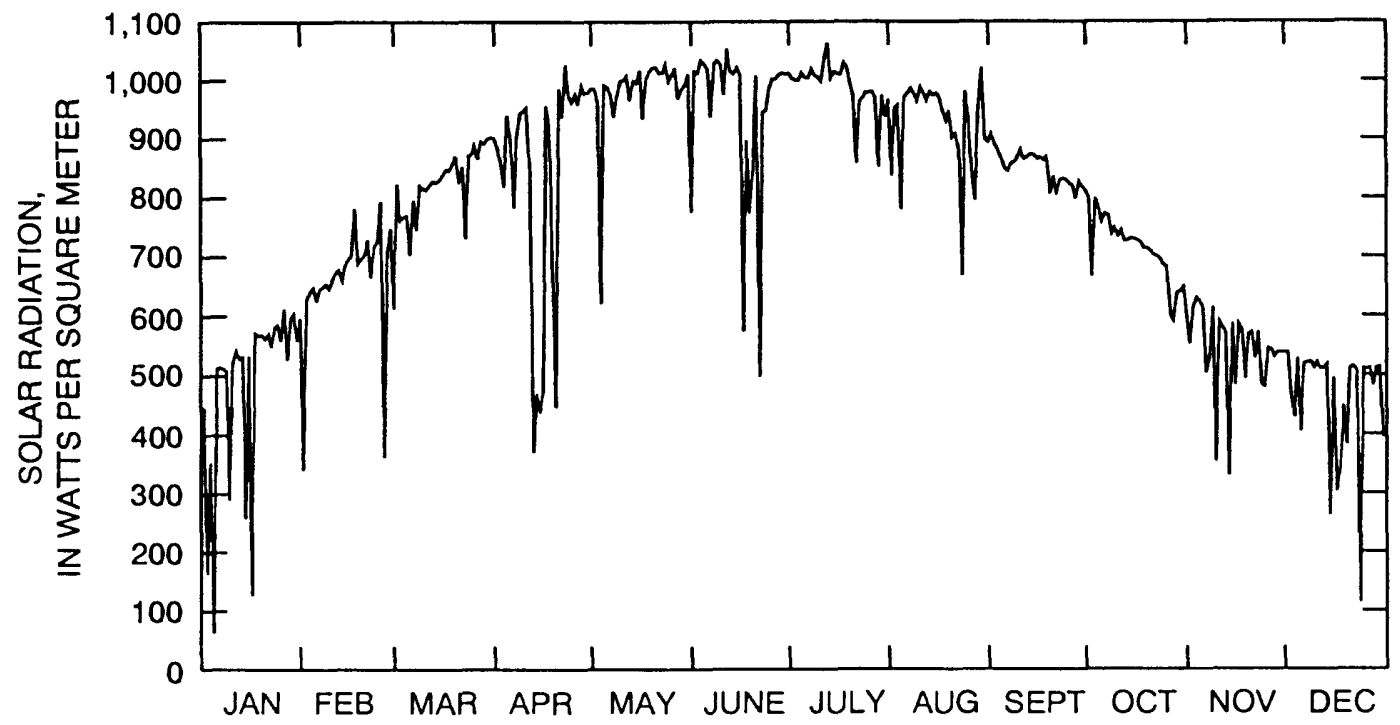

FIGURE 6.--Daily maximum solar radiation computed from hourly averaged values for 1988.

\section{Windspeed and wind-Vector Direction}

Daily mean, maximum, and minimum values of windspeed computed from hourly averaged values are listed in table 3 . Daily mean windspeeds are shown in figure 7. Daily mean windspeeds, for days with 24 values, ranged from a minimum of $1.2 \mathrm{~m} / \mathrm{s}$ on January 3 to a maximum of $7.8 \mathrm{~m} / \mathrm{s}$ on February 18. Hourly averages ranged from less than $1 \mathrm{~m} / \mathrm{s}$ (essentially zero) to almost $15 \mathrm{~m} / \mathrm{s}$.

Daily mean wind-vector direction (degrees Azimuth) and wind-vector magnitude (meters per second) presented in table 3 were determined from hourly wind-vector direction and magnitude values using the following equations (from Campbell Scientific, Inc., 1984, p. B-6 to B-10):

Daily mean wind-vector direction, in degrees $=\arctan (\bar{x}+\bar{y})$, 
where $\bar{x}=$ the sum of each hourly wind-vector magnitude multiplied by the sine of the hourly wind-vector direction and divided by the number of hourly values; $\bar{x}$ is positive to the east; and

$\bar{y}=$ the sum of each hourly wind-vector magnitude multiplied by the cosine of the hourly wind-vector direction and divided by the number of hourly values; $\bar{y}$ is positive to the north.

Daily mean wind-vector magnitude $=\sqrt{\bar{x}^{2}+\bar{y}^{2}}$,

Daily mean wind-vector direction in table 3 ranges from 0 to 360 degrees Azimuth (increasing degrees clockwise from north). The windvector direction calculated from equation 2 was transformed to degrees Azimuth on the basis of $\bar{x}$ and $\bar{y}$. For positive $\bar{x}$ and $\bar{y}$, the value calculated from equation 2 is the daily mean wind-vector direction in degrees Azimuth. For negative values of $\bar{y}$, the calculated value of wind-vector direction is added to 180 degrees, and for negative value of $\bar{x}$ and positive value of $\bar{y}$, the calculated value is added to 360 degrees. Because equation 2 cannot be used when $\bar{y}$ is zero, the mean wind-vector direction was set to 90 degrees Azimuth for positive values of $\bar{x}$ and 270 degrees Azimuth for negative values of $\bar{x}$.

Wind-vector directions for each month are summarized in diagrams called wind roses (figure 8 ). The diagrams were determined by: (1) summing the number of hourly wind-vector directions recorded during each month over 10-degree areas, (2) then dividing the sums by the total number of hourly values for each month, and (3) multiplying by 100 to obtain percent.

Trends shown in figure 8 indicate definite interseasonal variability in wind direction for 1988. Wind at the study site was predominantly from the northwest during January through March, but wind direction gradually shifted to the southeast and southwest during April through June. The wind was predominantly from the southeast and northwest during July and August. Wind began to shift back to the northwest during september until the predominant direction was again from the northwest during october through December.

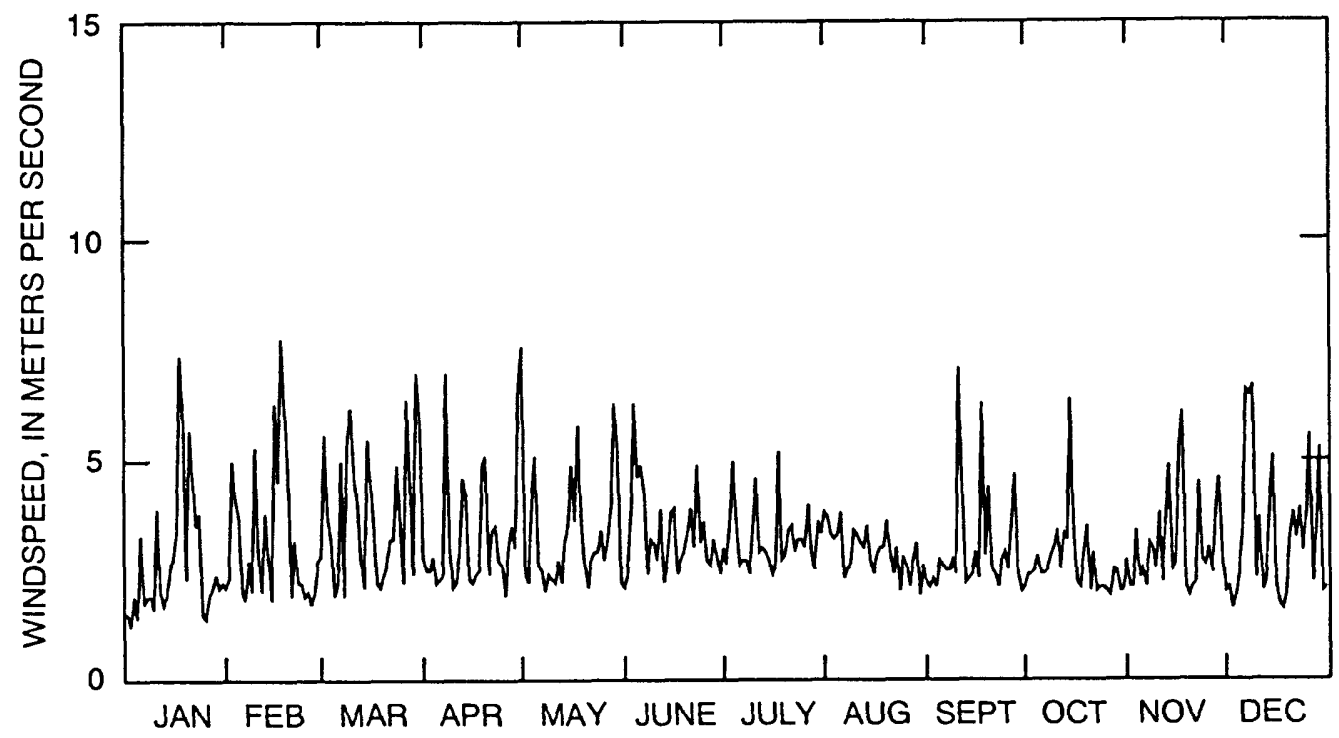

FIGURE 7.--Daily mean windspeed computed from hourly averaged values for 1988. 


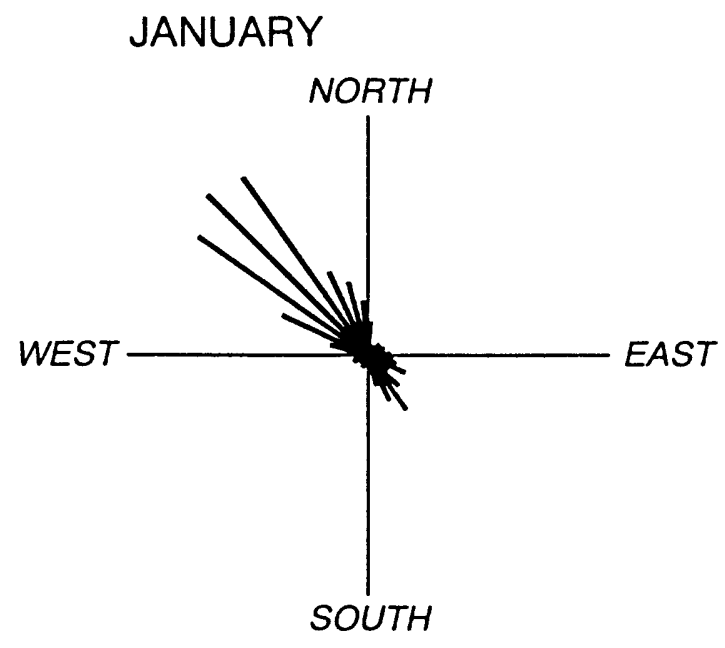

MARCH

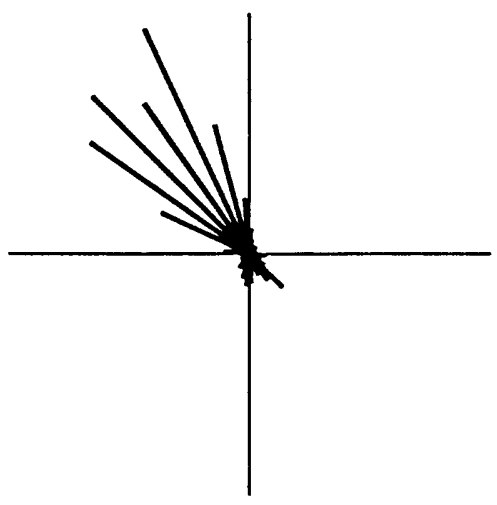

FEBRUARY

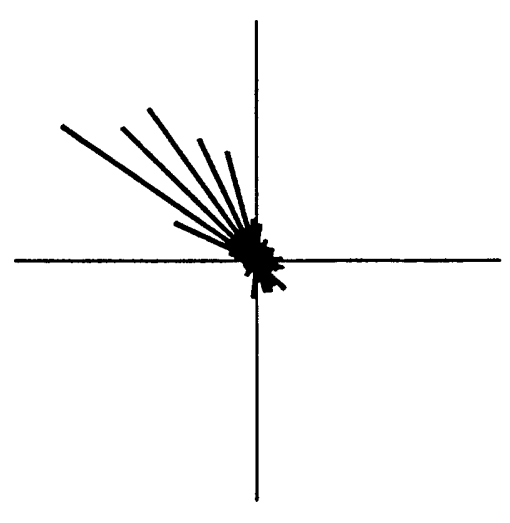

APRIL

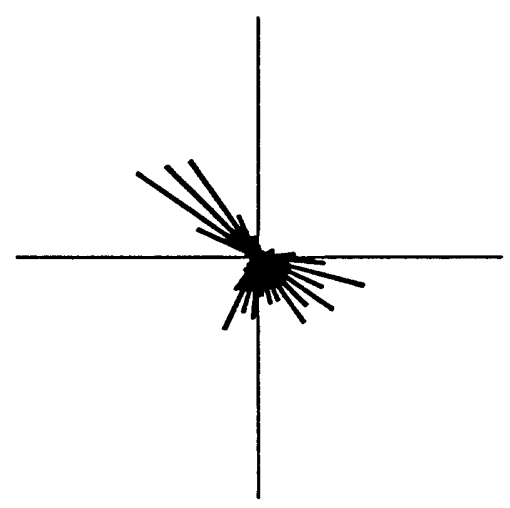

MAY

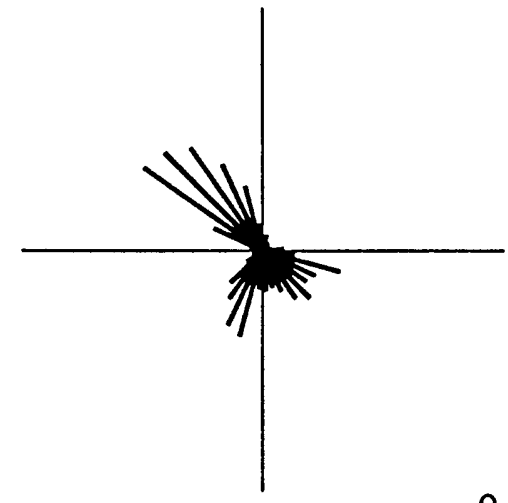

JUNE

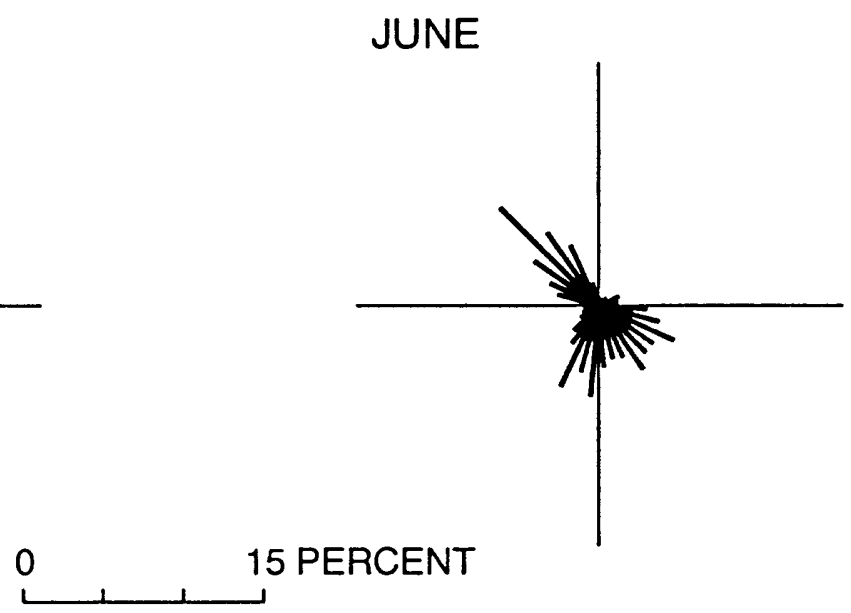

FIGURE 8.--Diagrams showing percentage of time wind is from a given direction for each month during 1988. Wind direction is summed over 10-degree arcs from hourly averaged data. 


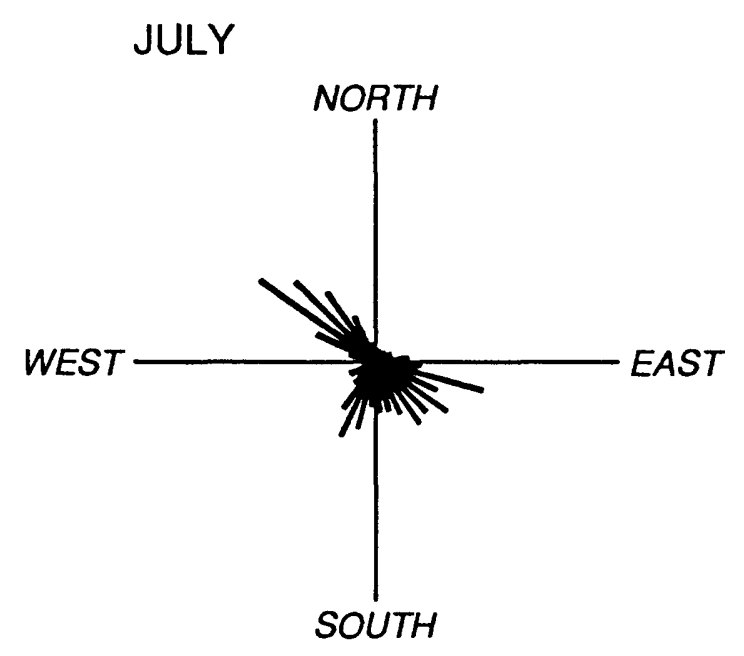

SEPTEMBER

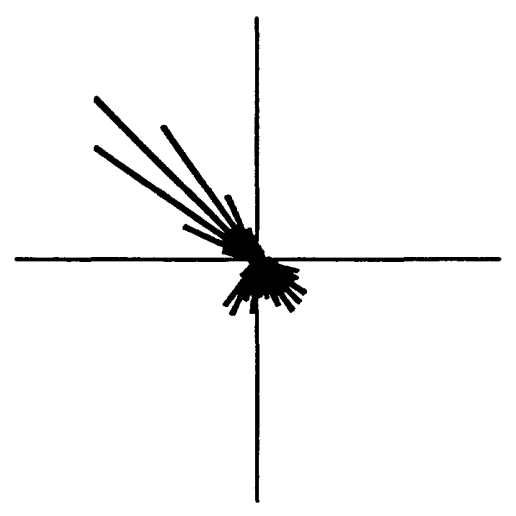

NOVEMBER

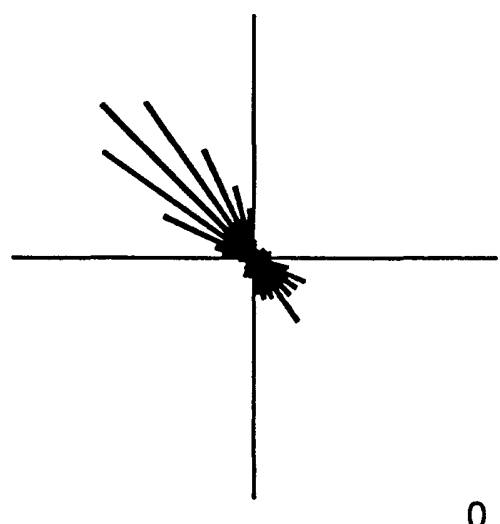

AUGUST

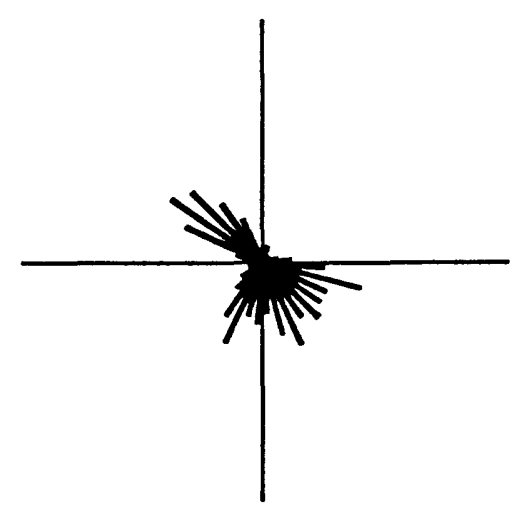

OCTOBER

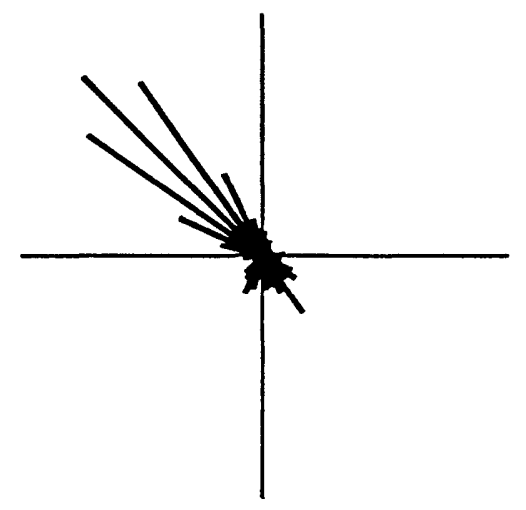

DECEMBER

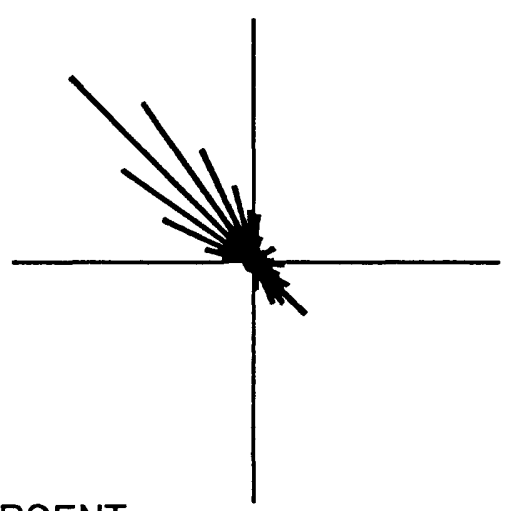
15 PERCENT

FIGURE 8.--Continued. 


\section{Precipitation}

Due to the infrequent nature of precipitation at the study site, precipitation is not included in table 3 , but is summarized in table 2 and figure 9. Due to malfunctions of the study site rain gage, precipitation totals for January 17 and 18 were based on records from the disposal facility (Robert Marchand, U.S. Ecology, written commun., 1988). Total measured precipitation for the year was $104.5 \mathrm{~mm}$. The 3-year average (1986-88) for the site is $105.5 \mathrm{~mm}$ (Wood and Fischer, 1991, p. 12; 1992, p. 12).

Monthly precipitation values measured at the study site are shown in figure 9A. Monthly precipitation ranged from $27.8 \mathrm{~mm}$ in April to zero in July, october, and November. Typically, most precipitation occurred during the winter months, and least during the summer. Winter precipitation was from regional frontal systems, whereas summer precipitation was from local convective storms.

Figure 9B compares monthly precipitation at the study site (altitude $847 \mathrm{~m}$ ) and two National Oceanic and Atmospheric Administration (NOAA) sites. One of the these sites is designated Beatty $8 \mathrm{~N}$ and is $12.9 \mathrm{~km}$ north of Beatty $\left(37^{\circ} 00^{\prime}\right.$ N., $116^{\circ} 43^{\prime}$ W.) at an altitude of $1,007 \mathrm{~m}$ (figure 1); the other is Amargosa Farms, which is about $35 \mathrm{~km}$ southeast of the study site $\left(36^{\circ} 34^{\prime} \mathrm{N}\right.$., $\left.116^{\circ} 28^{\prime} \mathrm{W}^{\prime}\right)$ at an altitude of $747 \mathrm{~m}$. Monthly values differ considerably between sites.

Daily precipitation totals are shown in figure 9C and table 2. The largest events occurred during the winter and spring months. Daily precipitation exceeded $5 \mathrm{~mm}$ on six days--one each in January, February, April, and September, and two in August. Summer storms are usually of short duration but can be intense. Only two summer storms produced more than $5 \mathrm{~mm}$ of precipitation; those were on August $25(5.8 \mathrm{~mm}$ in 90 minutes) and August $28(14.2 \mathrm{~mm}$ in 30 minutes).

TABLE 2.--Daily total precipitation at study site for 1988. All unlisted dates had no precipitation

\begin{tabular}{|c|c|c|c|c|c|}
\hline Month & Day & $\begin{array}{l}\text { Total } \\
\text { precipitation } \\
\text { (millimeters) }\end{array}$ & Month & Day & $\begin{array}{c}\text { Total } \\
\text { precipitation } \\
\text { (millimeters) }\end{array}$ \\
\hline $\begin{array}{l}\text { January } \\
\text { January } \\
\text { January } \\
\text { January }\end{array}$ & $\begin{array}{r}4 \\
5 \\
17 \\
18\end{array}$ & $\begin{array}{r}0.5 \\
1.8 \\
22.1 \\
3.3\end{array}$ & $\begin{array}{l}\text { May } \\
\text { May } \\
\text { June }\end{array}$ & $\begin{array}{r}5 \\
29\end{array}$ & $\begin{array}{r}1.5 \\
1.5 \\
.3\end{array}$ \\
\hline $\begin{array}{l}\text { February } \\
\text { February } \\
\text { February } \\
\text { February }\end{array}$ & $\begin{array}{r}2 \\
27 \\
28 \\
29\end{array}$ & $\begin{array}{l}.5 \\
8.6 \\
1.8 \\
2.8\end{array}$ & $\begin{array}{l}\text { August } \\
\text { August } \\
\text { August } \\
\text { August }\end{array}$ & $\begin{array}{l}25 \\
26 \\
28 \\
30\end{array}$ & $\begin{array}{r}5.8 \\
1.0 \\
14.2 \\
.3\end{array}$ \\
\hline March & 1 & 2.5 & $\begin{array}{l}\text { September } \\
\text { September }\end{array}$ & $\begin{array}{l}21 \\
23\end{array}$ & $\begin{array}{r}7.6 \\
.3\end{array}$ \\
\hline $\begin{array}{l}\text { April } \\
\text { April } \\
\text { April } \\
\text { April } \\
\text { April } \\
\text { April }\end{array}$ & $\begin{array}{l}13 \\
14 \\
15 \\
16 \\
20 \\
21\end{array}$ & $\begin{array}{r}.3 \\
3.8 \\
22.1 \\
.3 \\
.3 \\
1.0\end{array}$ & December & 22 & .3 \\
\hline
\end{tabular}


A. Monthly precipitation at study site

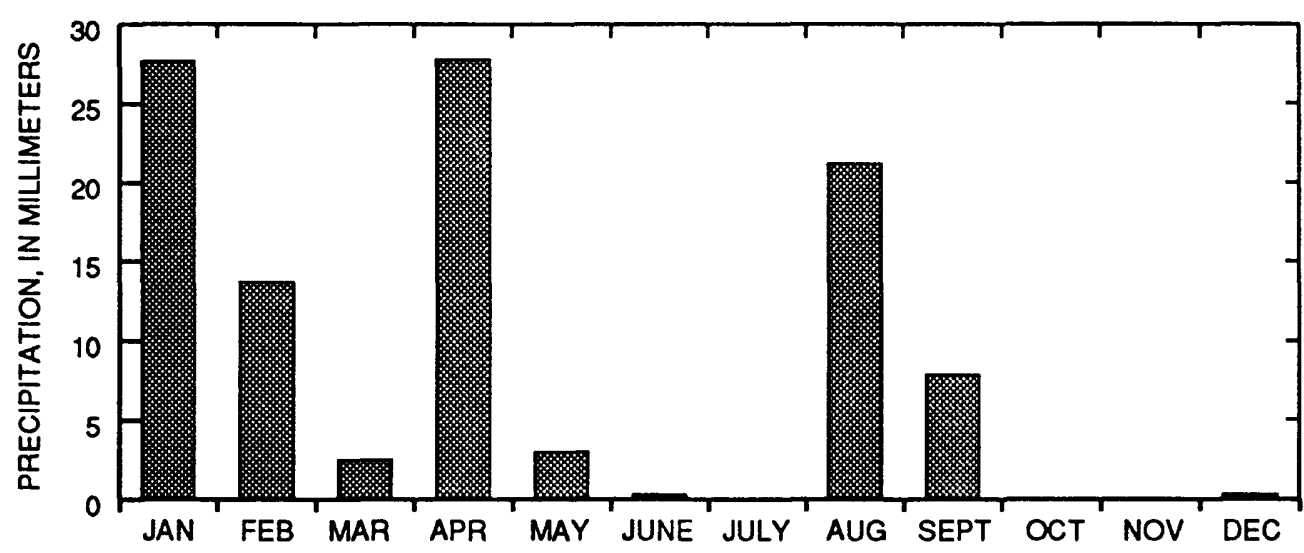

B. Monthly precipitation at three sites

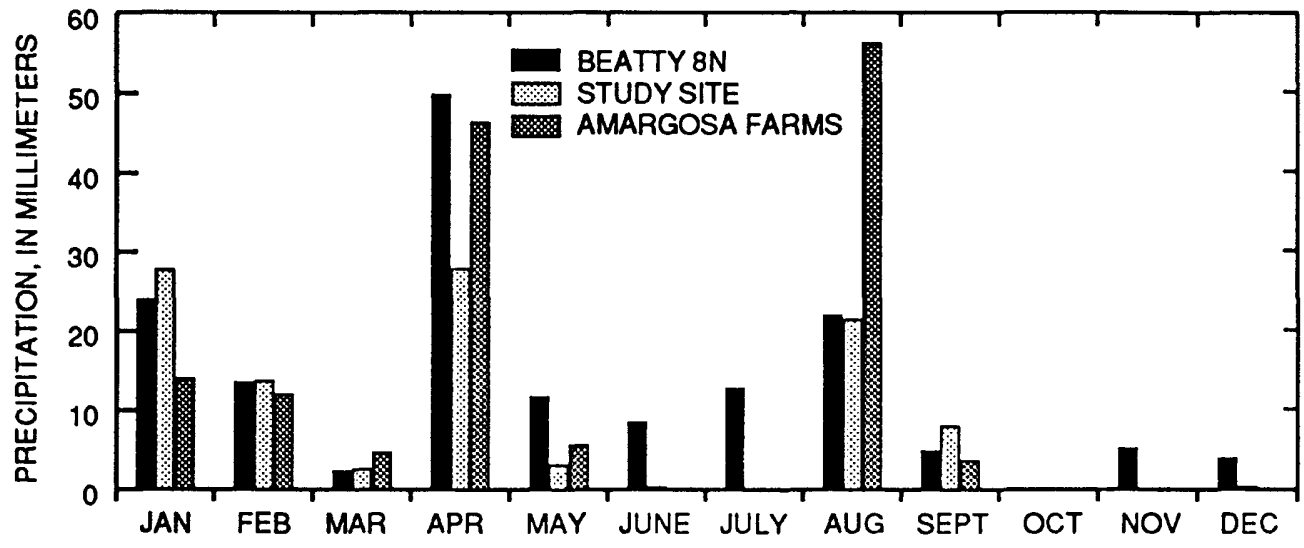

C. Daily precipitation at study site

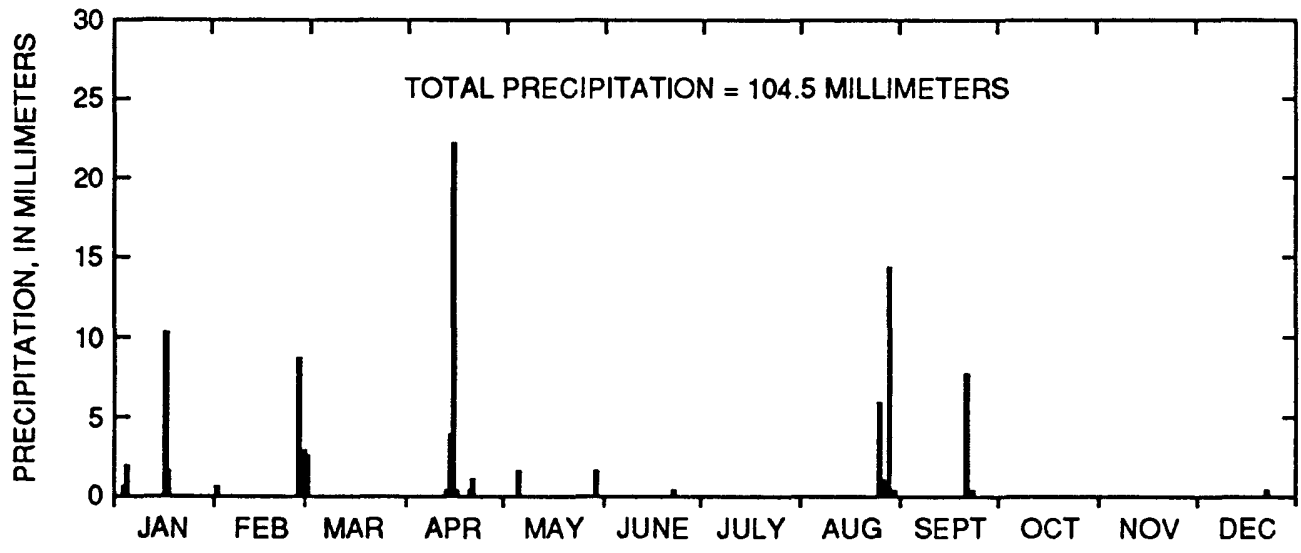

FIGURE 9.--Precipitation at or near study site for 1988 . (A) Monthly precipitation at study site. (B) Comparison of monthly precipitation at study site with monthly precipitation at two National Oceanographic and Atmospheric Administration (NOAA) sites (Beatty 8N and Amargosa Farms) near study site. (C) Daily precipitation at study site. 


\section{SUMMARY}

Meteorological data were collected adjacent to a low-level radioactive-waste facility near Beatty, Nev., during calendar year 1988 in support of an ongoing study to estimate the potential for downward movement of radionuclides into the unsaturated sediments beneath wasteburial trenches at the facility. This report provides daily averaged values of air temperature, relative humidity, vapor pressure, incident solar radiation, windspeed, wind direction, and daily totals of precipitation. A general description of instrumentation used and sensor installation is given.

The minimum hourly averaged air temperature for the year was $-10.2^{\circ} \mathrm{C}$ in December and the maximum was $45.3^{\circ} \mathrm{C}$ in July. Hourly averaged values for relative humidity ranged from about 12 percent to more than 80 percent. Daily values for maximum solar radiation ranged from $63 \mathrm{~W} / \mathrm{m}^{2}$ in January to $1,064 \mathrm{~W} / \mathrm{m}^{2}$ in July. Hourly vapor pressures ranged from a minimum of $0.09 \mathrm{kPa}$ in December, to a maximum of $2.22 \mathrm{kPa}$ in August. Daily mean windspeed ranged from 1.2 to $7.8 \mathrm{~m} / \mathrm{s}$. Wind direction determined from hourly averaged data was predominantly from the northwest from January through March and October through December. The wind shifted during the summer months and was commonly from the southeast and northwest. Total measured precipitation for the year was $104.5 \mathrm{~mm}$. Monthly precipitation ranged from $27.8 \mathrm{~mm}$ in April to zero in July, October, and November. Daily precipitation totaled more than $5 \mathrm{~mm} \mathrm{six}$ times during 1988 .

\section{REFERENCES CITED}

Andraski, B.J., 1990, water movement and trench stability at a simulated arid burial site for low-level radioactive waste near Beatty, Nevada: LaGrange, Ill., American Nuclear Society, Nuclear Waste Isolation in the Unsaturated Zone, Las Vegas, Nev., September, 1989, Proceedings, p. 166-173.

Campbell, G.S., 1986, Introduction to environmental biophysics (3d ed.): New York, Springer-Verlag, $159 \mathrm{p}$.

Campbell Scientific, Inc., 1984, CR21 micrologger operators manual: Logan, Utah, Campbell Scientific, Inc., Revision No. Im CR21-10, 81 p.

Fischer, J.M., 1990, Geohydrology of the near-surface unsaturated zone adjacent to the disposal site for low-level radioactive waste near Beatty, Nevada, in Bedinger, M.S., and Stevens, P.R., eds., Safe disposal of radionuclides in low-level radioactive-waste repository sites--Low-level radioactive-waste disposal workshop, U.S. Geological Survey, July 10-16, 1987, Big Bear Lake, California, Proceedings: U.S. Geological Survey Circular 1036, p. 57-61.

Lowe, P.R., 1977, An approximating polynomial for the computation of saturation vapor pressure: Journal of Applied Meteorology, v. 16, no. 1 , p. 100-103.

Morgan, D.S., and Fischer, J.M., 1984, Unsaturated-zone instrumentation in coarse alluvial deposits of the Amargosa Desert near Beatty, Nevada, in Proceedings of Sixth Annual Participants' Information Meeting--U.S. Department of Energy Low-Level Waste Management Program: Available from National Technical Information Service, U.S. Department of Commerce, Springfield, VA 22161, CONF-8409115, p. 617-630.

Nichols, W.D., 1987, Geohydrology of the unsaturated zone at the burial site for low-level radioactive waste near Beatty, Nye County, Nevada: U.S. Geological Survey Water-Supply Paper $2312,57 \mathrm{p}$.

Wood, J.L., and Fischer, J.M., 1991, Selected meteorological data for an arid site near Beatty, Nye County, Nevada, calendar year 1986: U.S. Geological Survey Open-File Report 91-189, 27 p.

----1992, Selected meteorological data for an arid site near Beatty, Nye County, Nevada, calendar year 1987: U.S. Geological Survey Open-File Report 92-59, $27 \mathrm{p}$. 


\section{BASIC DATA}

This section contains table 3 , which is a listing of daily averaged meteorological data (except precipitation, which is totaled) collected at the study site for 1988 . 


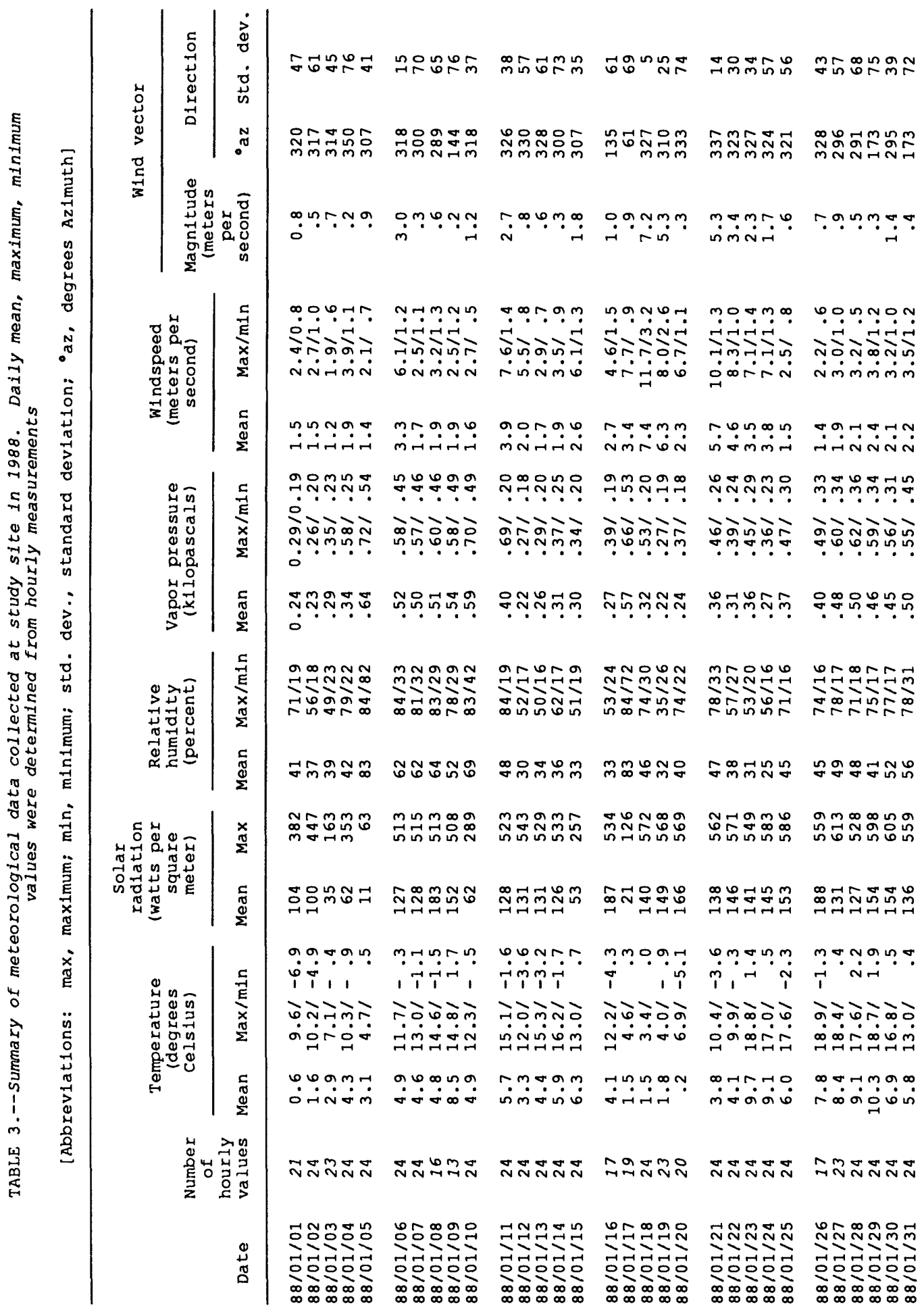




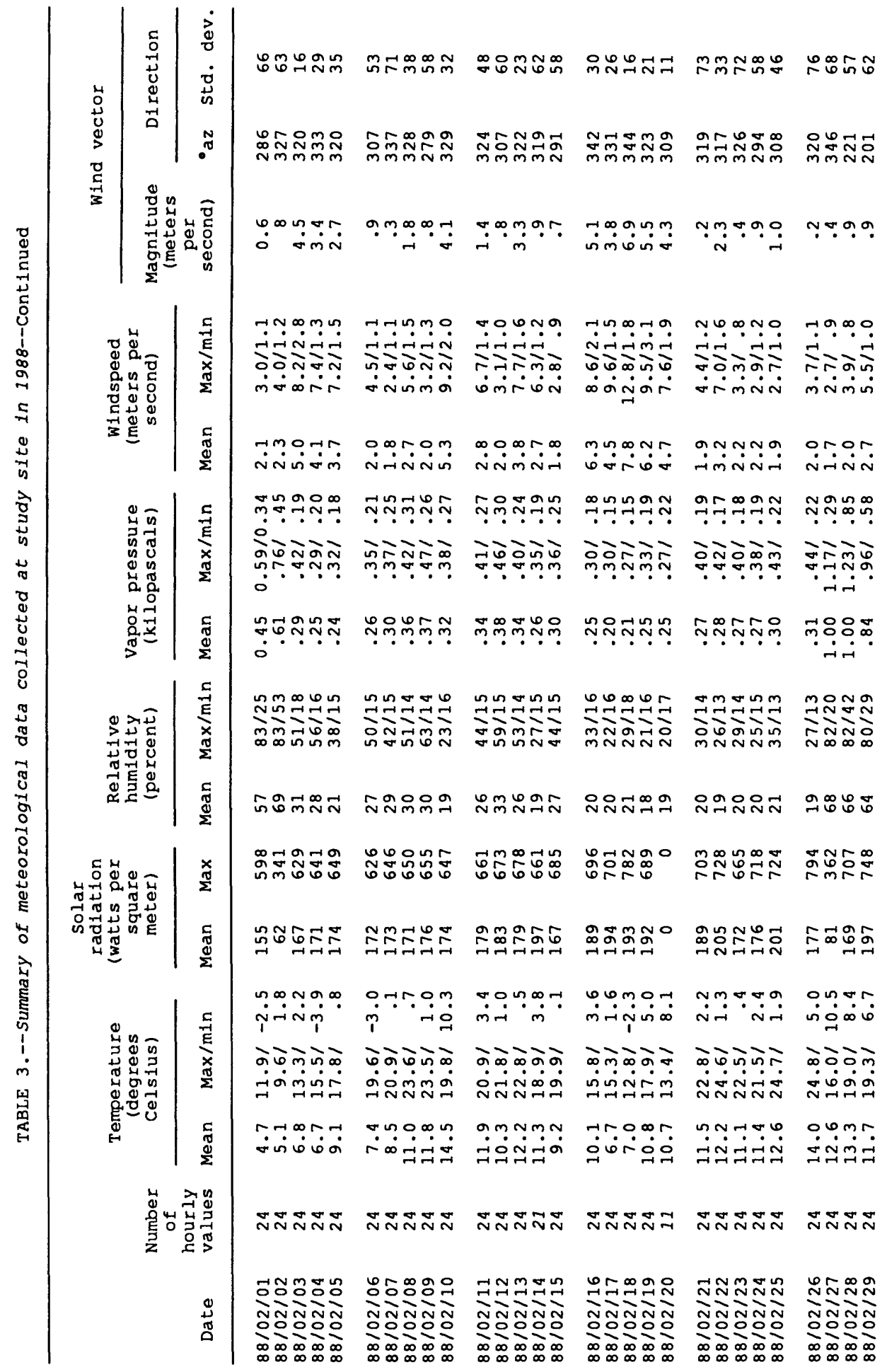




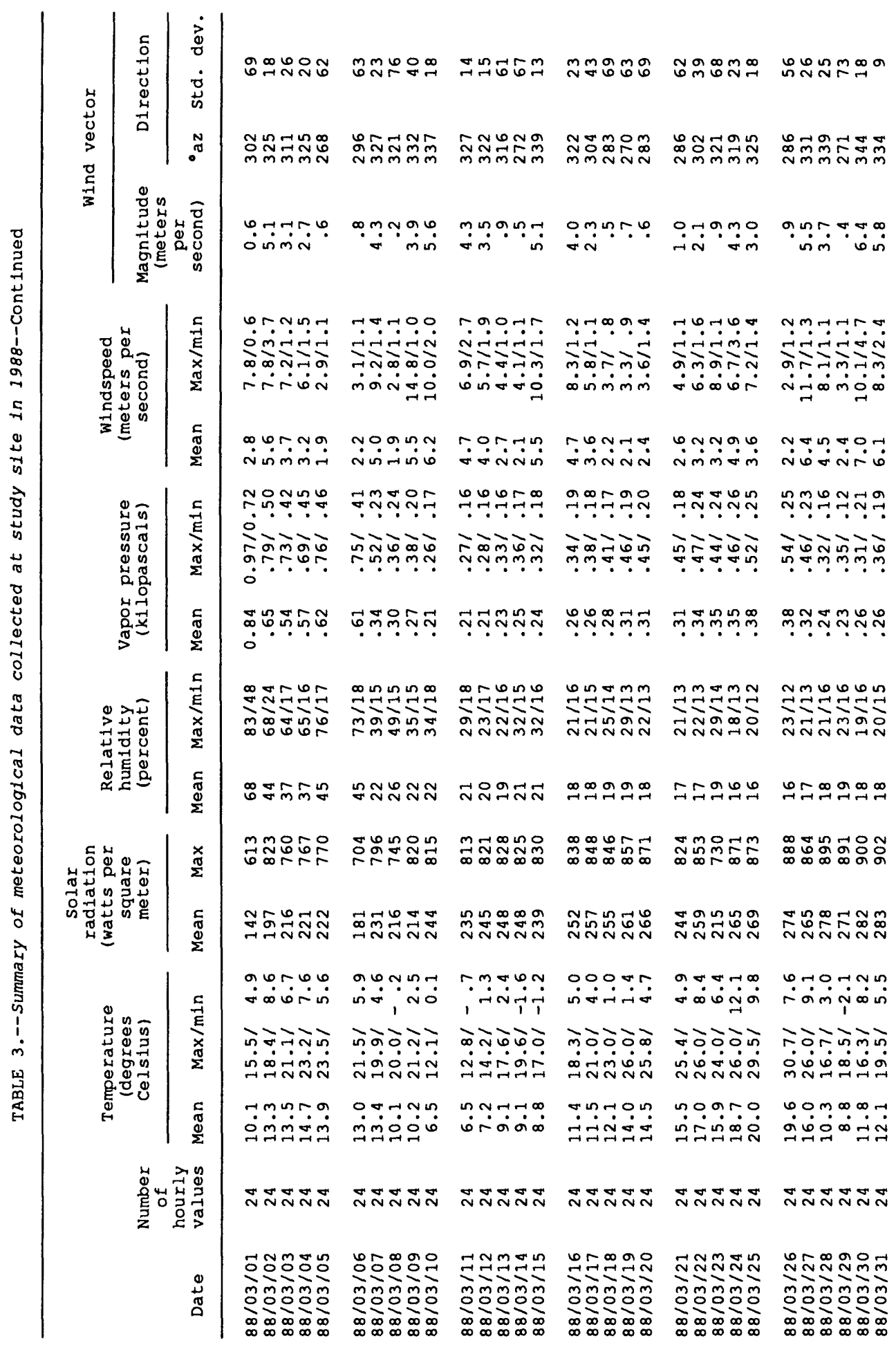




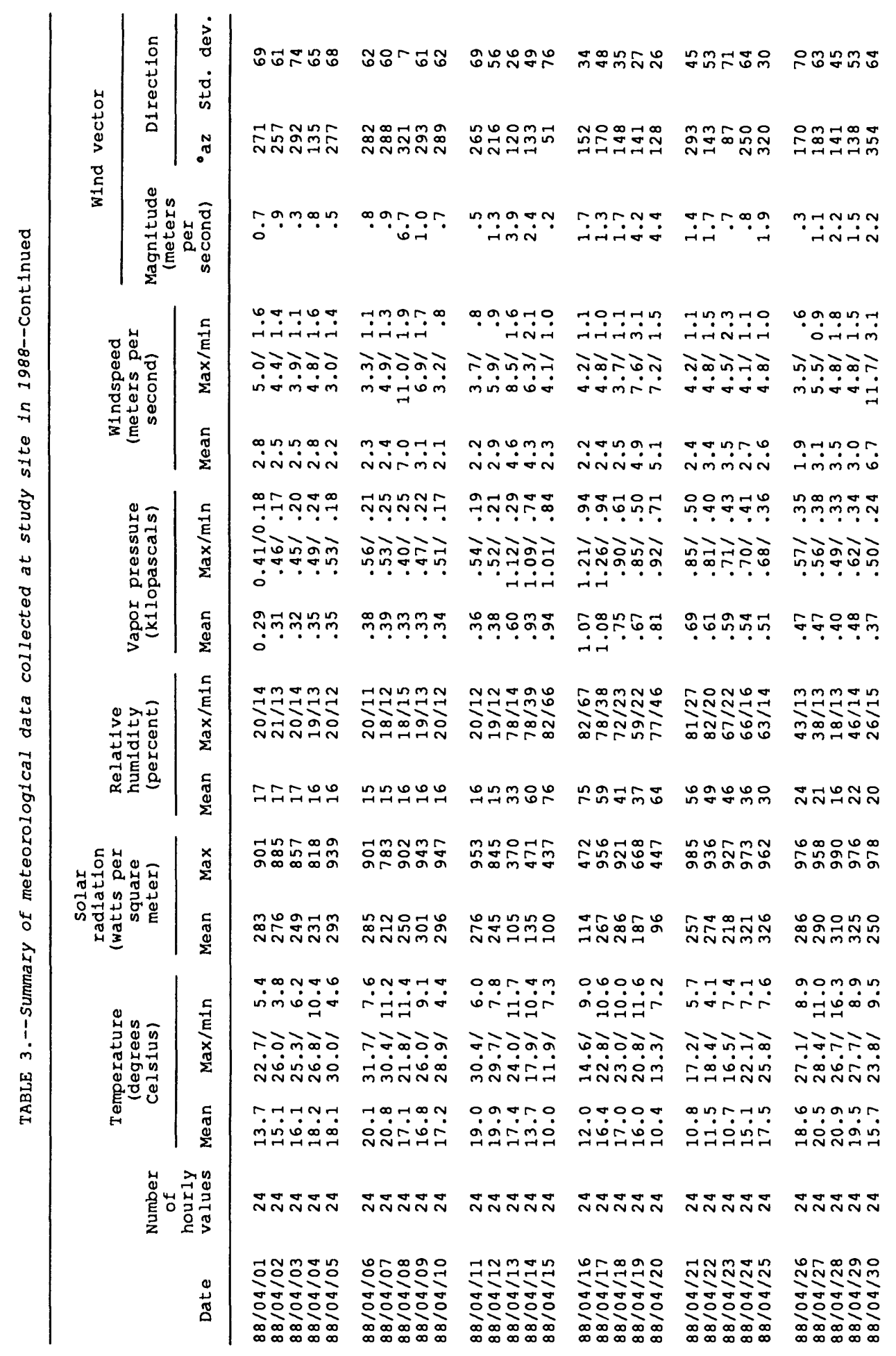




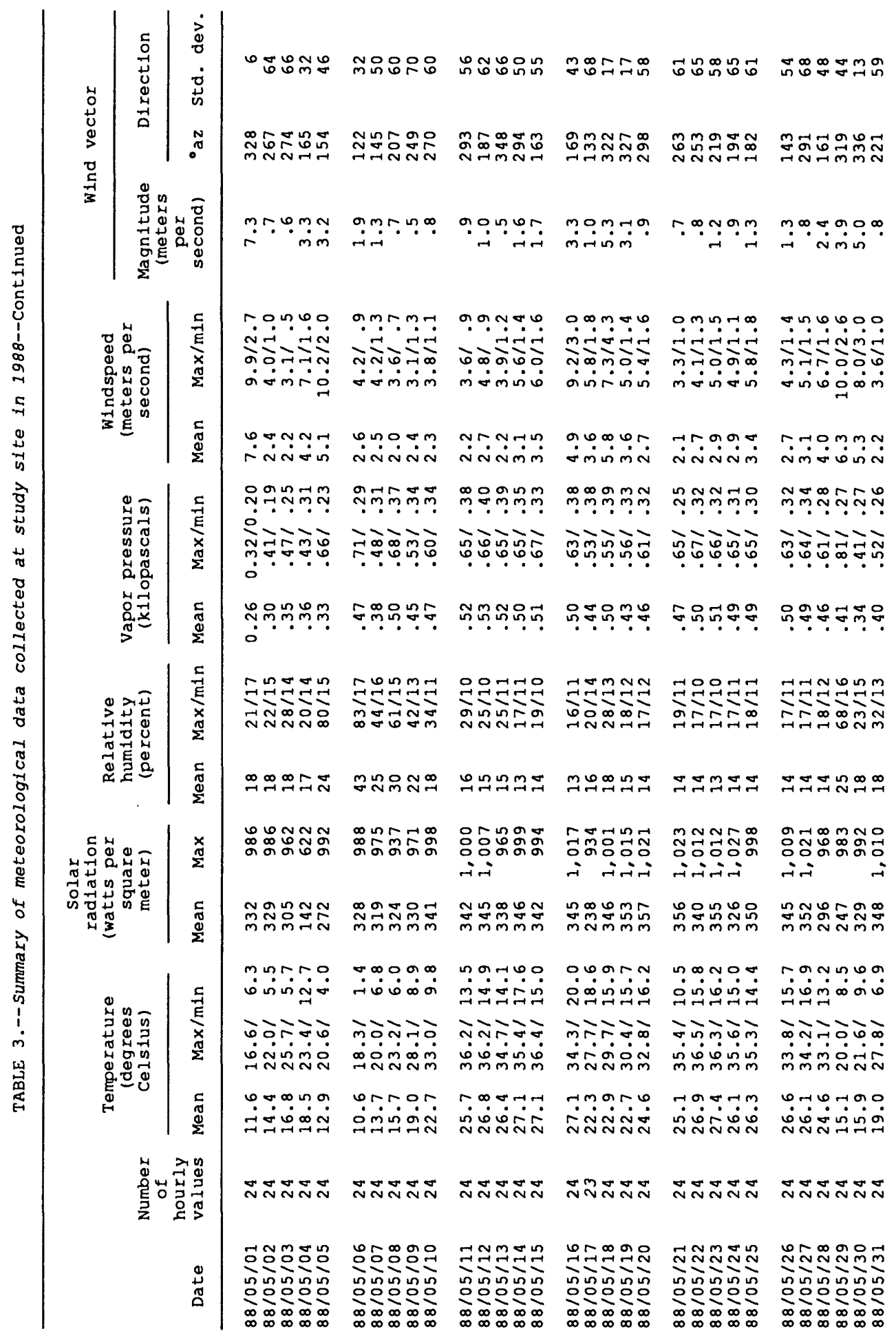




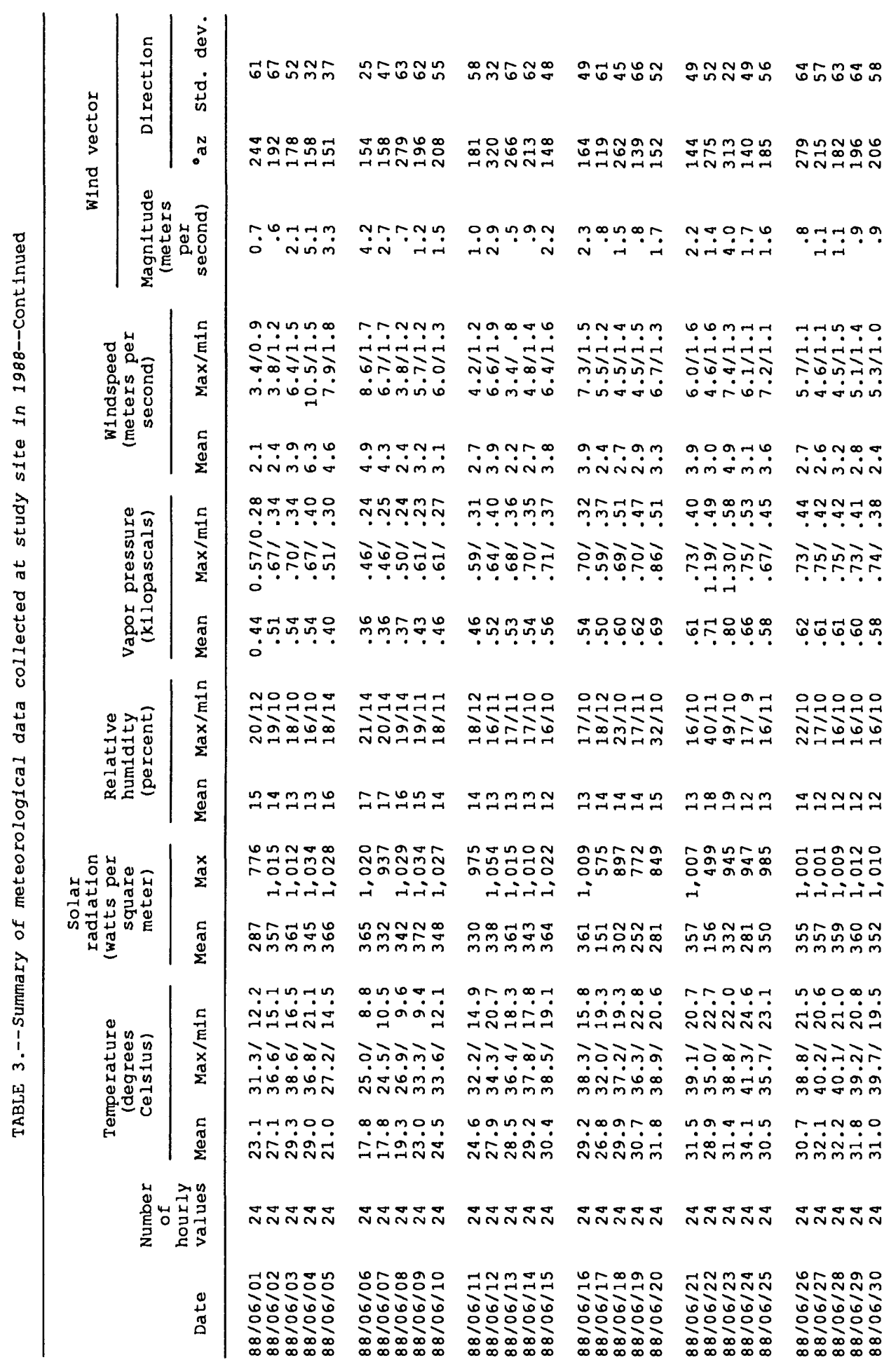




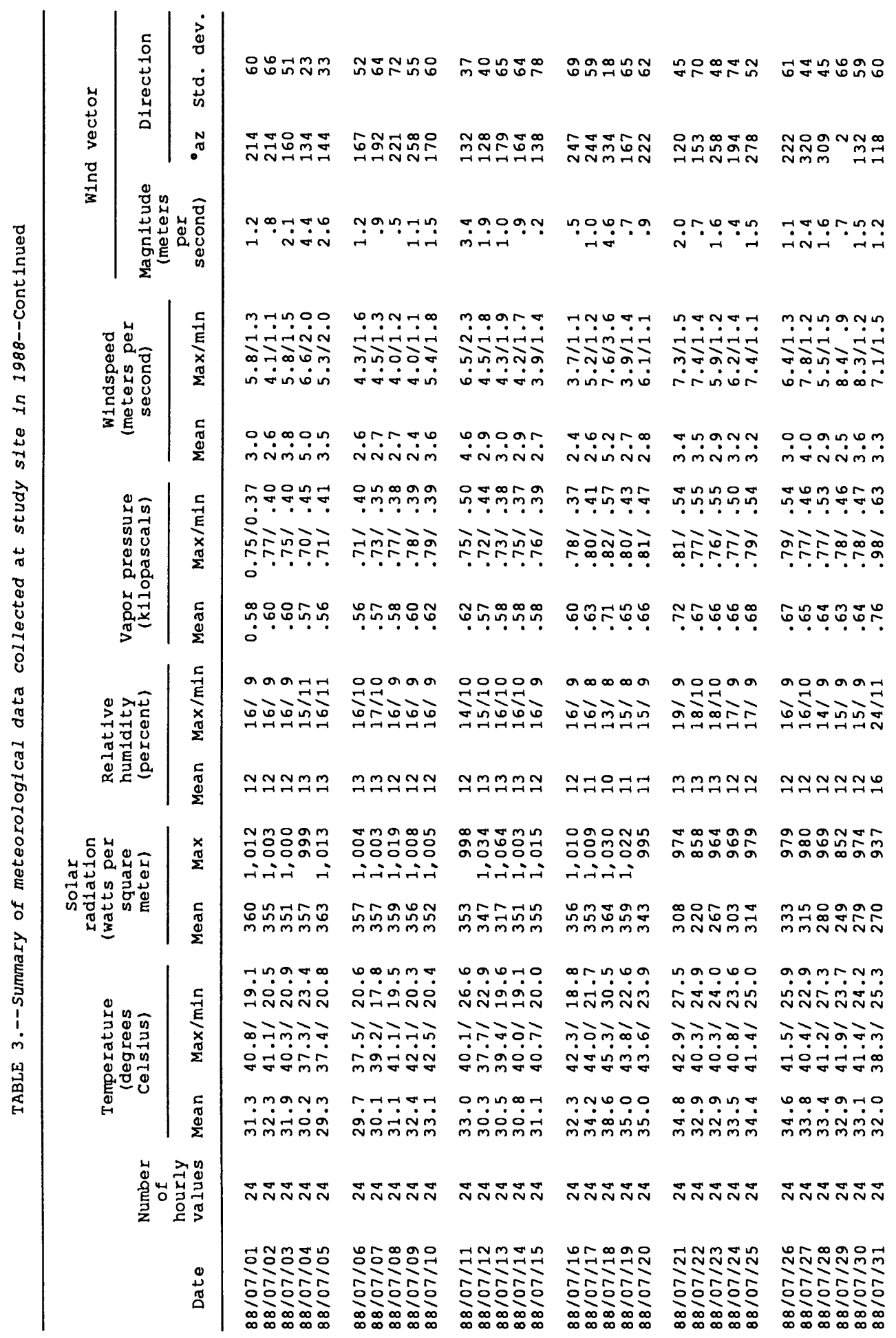




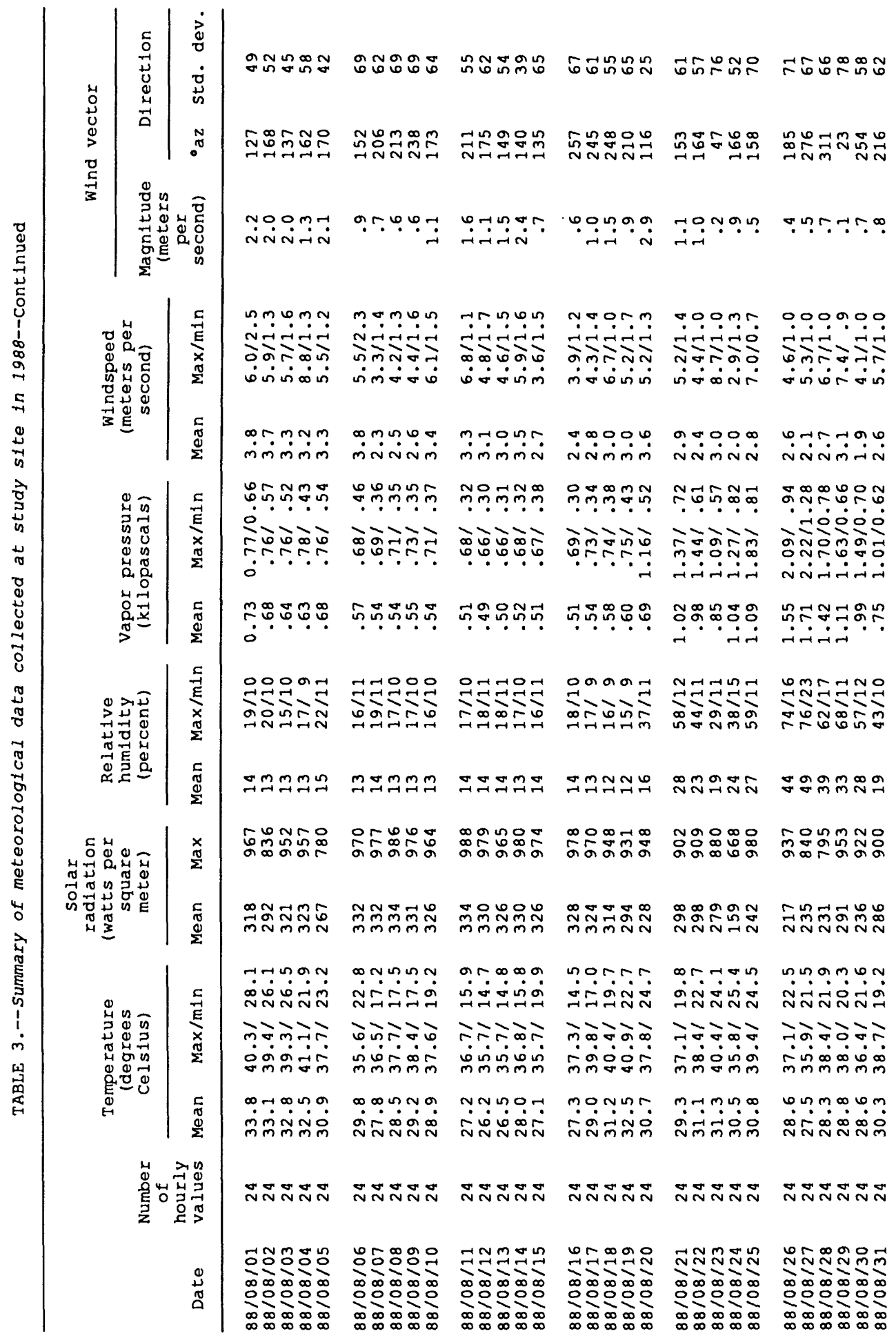




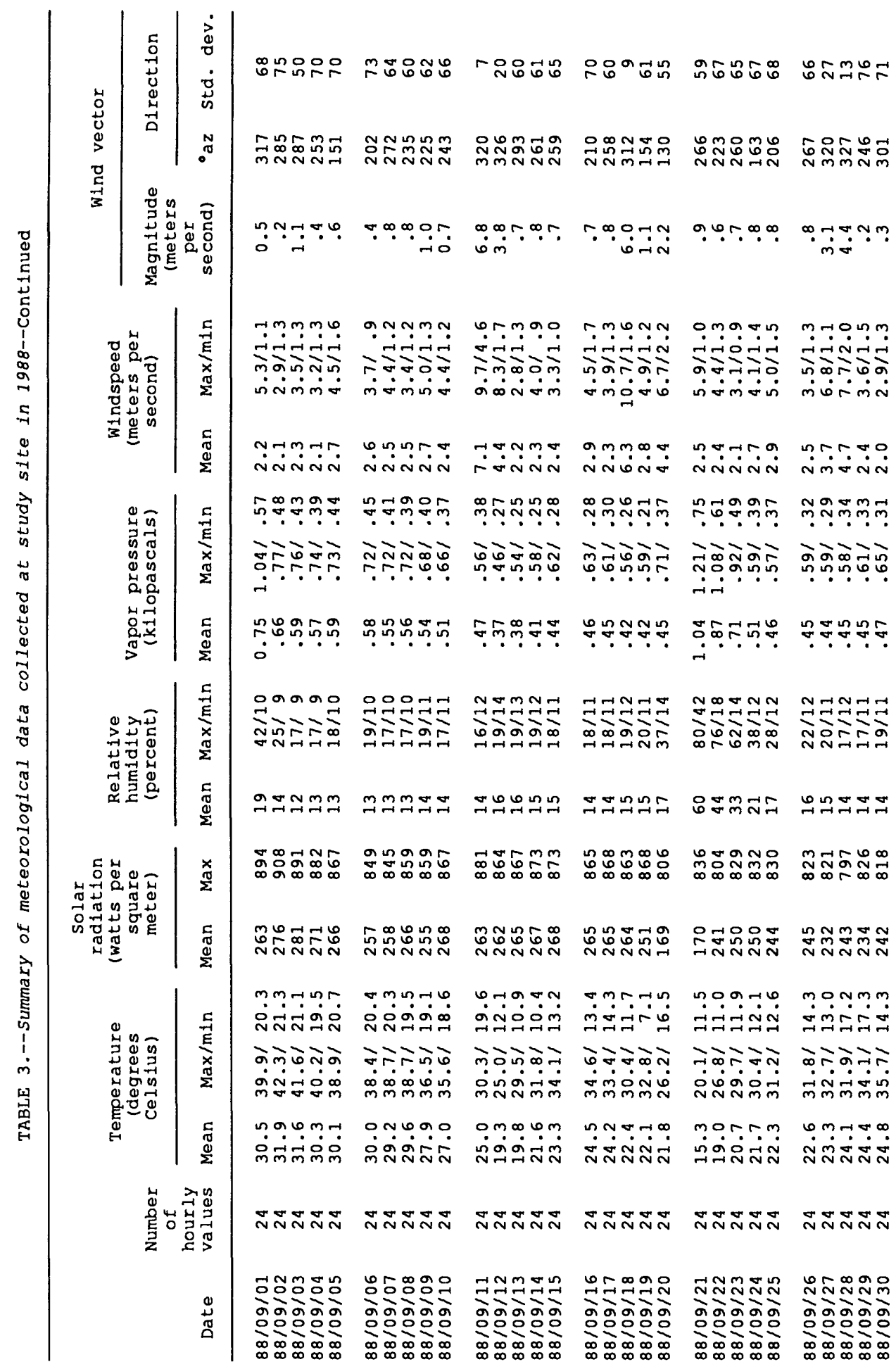




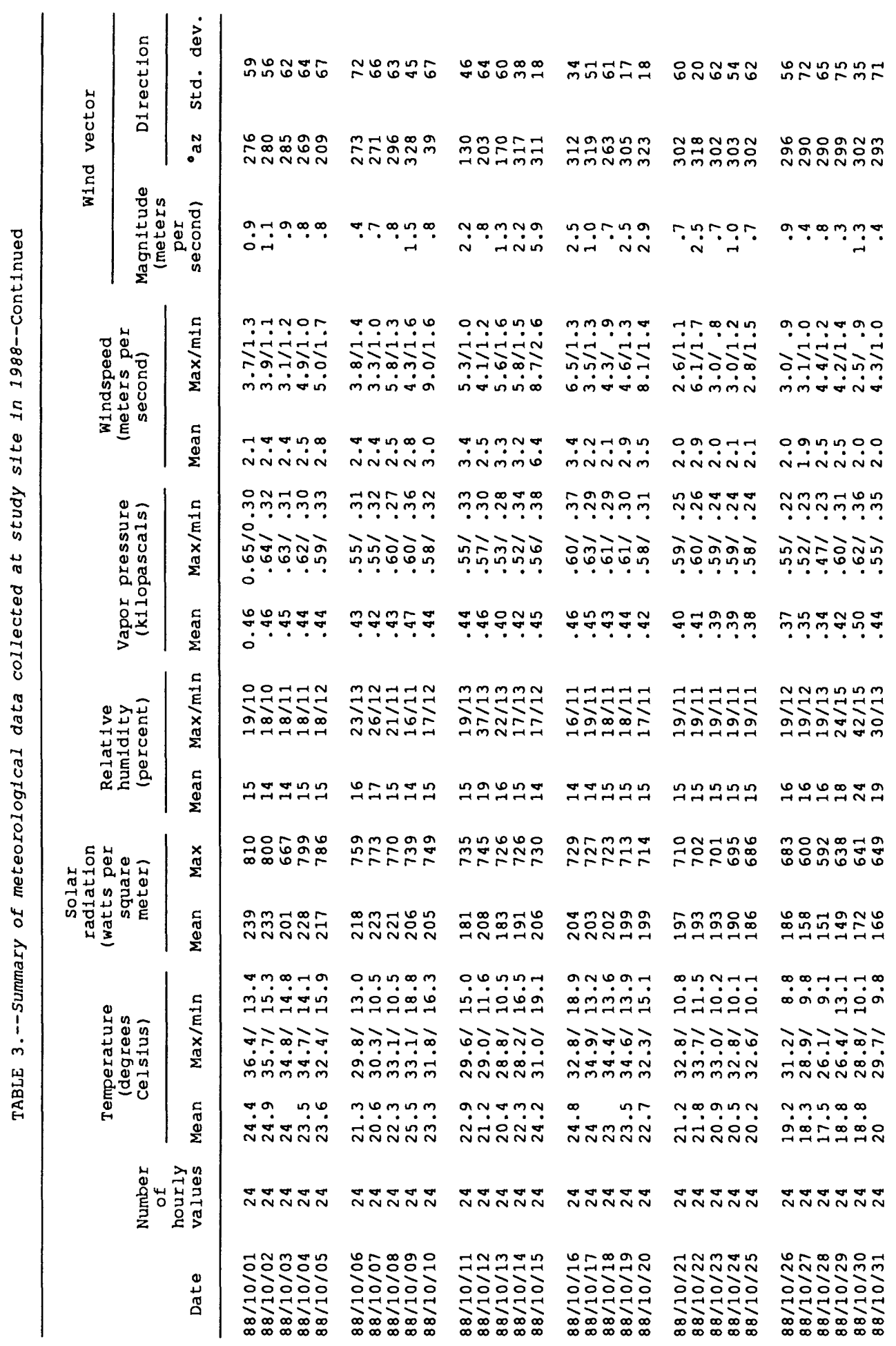




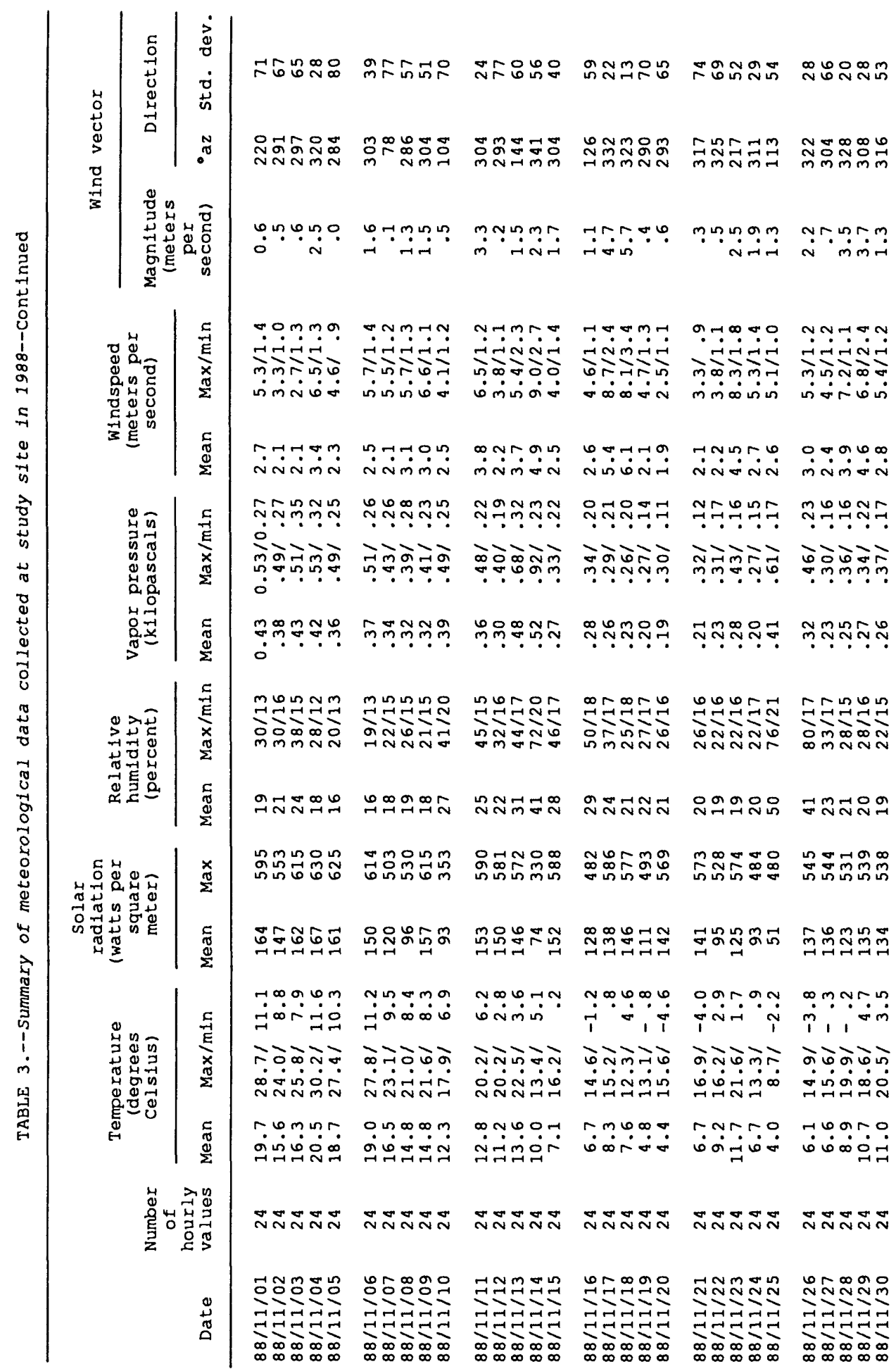




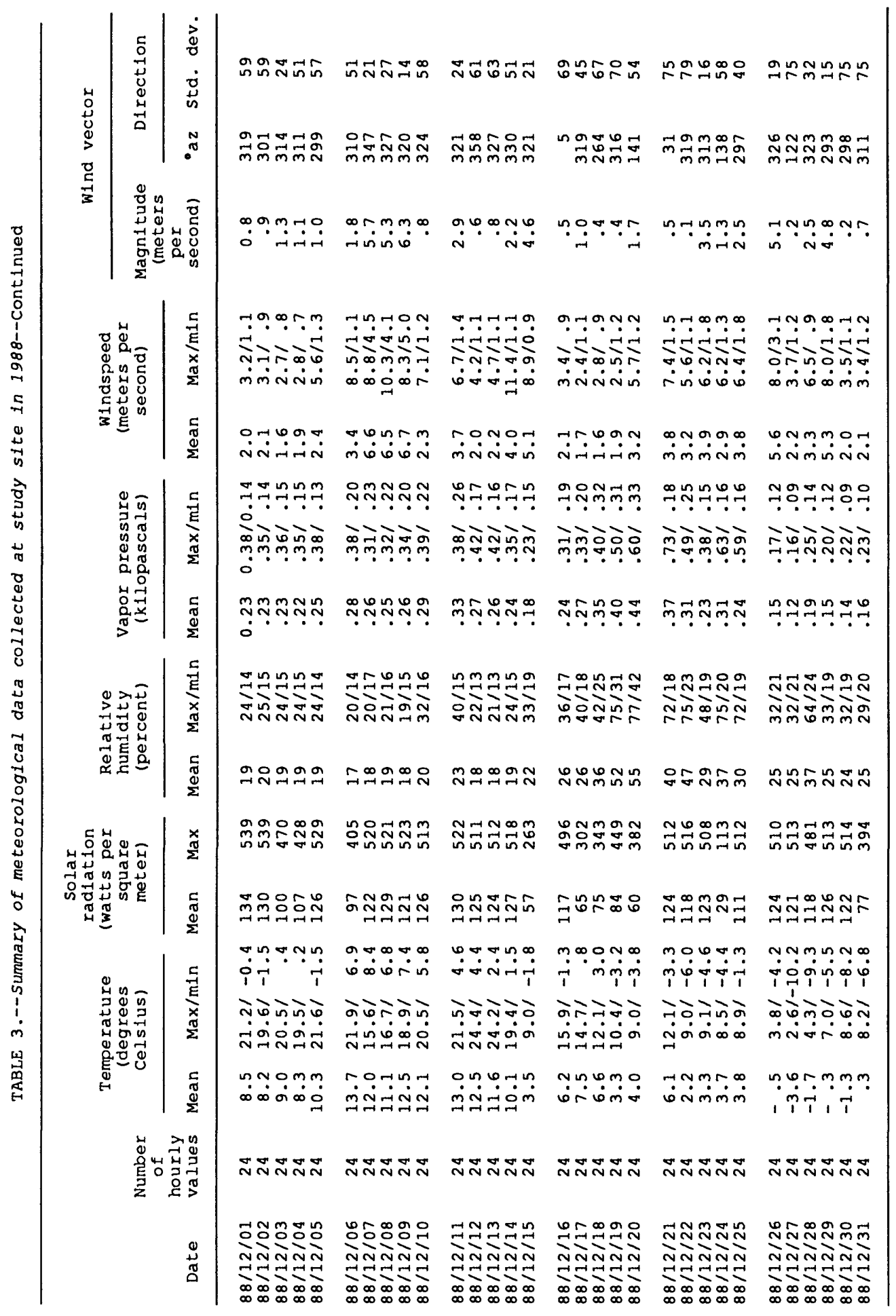

